\title{
Petrophysical Properties of the Middle Jurassic Carbonates in the PICOREF Sector (South Champagne, Paris Basin, France)
}

\author{
J. Delmas, E. Brosse and P. Houel \\ Institut français du pétrole, IFP, 1-4 avenue de Bois-Préau, 92852 Rueil-Malmaison Cedex - France \\ e-mail: jocelyne.delmas@ifp.fr - etienne.brosse@ifp.fr - pascal.houel@ifp.fr
}

\begin{abstract}
Résumé - Propriétés pétrophysiques du Dogger carbonaté dans le Secteur PICOREF (Sud Champagne, bassin de Paris, France) - Cet article, réalisé dans le cadre du Projet PICOREF ${ }^{(1)}$ pour le stockage de $\mathrm{CO}_{2}$ dans les aquifères du bassin parisien, présente une importante base de données pétrophysiques issues des nombreux puits pétroliers forés dans le Secteur PICOREF (sud-est du bassin parisien) entre 1953 et 2001. Ces données concernent les trois aquifères salins du Dogger carbonaté susceptibles d'être utilisés pour séquestrer du $\mathrm{CO}_{2}$ : l'Oolithe Blanche et le Comblanchien, d'âge Bathonien supérieur, ainsi que la Dalle Nacrée d'âge Callovien inférieur. Recoupés à des altitudes de -1230 à $-1750 \mathrm{~m} / \mathrm{mer}$ dans le secteur étudié, ces réservoirs carbonatés, dont l'épaisseur cumulée est de $150 \mathrm{~m}$ environ, affleurent en Bourgogne, à $80 \mathrm{~km}$ au sud-est du « Secteur », où ils sont exploités dans plusieurs carrières.

L'analyse des 6800 mesures classiques (porosité et perméabilité) rassemblées ici a permis d'améliorer la connaissance des qualités pétrophysiques des réservoirs. Les mesures spéciales de porosimétrie mercure ont permis de caractériser le milieu poreux.
\end{abstract}

Abstract - Petrophysical Properties of the middle Jurassic Carbonates in the PICOREF Sector (South Champagne, Paris Basin, France) - This article, carried out as part of the PICOREF Project for the $\mathrm{CO}_{2}$ storage in the aquifers of the Paris Basin, presents an important petrophysical database from the numerous petroleum wells drilled in the PICOREF Sector (south-eastern part of the Paris Basin) between 1953 and 2001. These core data concern the three saline carbonated aquifers of the Middle Jurassic: the Oolithe Blanche and the Comblanchien formations, Upper Bathonian age, and the Dalle Nacrée formation, Lower Callovian age, that would be used for the $\mathrm{CO}_{2}$ sequestration. Located at -1230 to $-1750 \mathrm{~m}$ sub sea in the studied sector, these carbonate reservoirs which cumulative thickness is about $150 \mathrm{~m}$, outcrop in the Burgundy region, at about $80 \mathrm{~km}$ south-eastern the Sector where they are exploited in several quarries.

The analysis of the 6800 routine measurements (porosity and permeability) gathered for this study allowed to improve the knowledge of the petrophysical properties. Special measurements (mercury injection tests) allowed to characterize the porous medium.

(1) Plégeage du $\mathrm{CO}_{2}$ dans des REservoirs géologiques en France. 


\section{INTRODUCTION}

Since 2005, the south-eastern part of the Paris Basin has been studied with the objective of selecting sites where geological storage of $\mathrm{CO}_{2}$ could be tested at the pilot scale $\left(10^{3}-10^{6}\right.$ tons of $\mathrm{CO}_{2}$ stored). The PICOREF project addressed two types of reservoirs for storage: deep saline aquifers, and depleted hydrocarbon fields. Carbonate formations of Middle Jurassic age, and sandstone formations of Triassic age, were considered as the main aquifer objectives. A first step of the project led to define a geographic area, named the "Sector", as the most appropriate for further selection of potential storage sites (Brosse et al., this issue). Moreover, PICOREF had access to the petroleum data of the Saint-Martin de Bossenay (SMB) oilfield, where the reservoirs are located in carbonate formations of Middle Jurassic age.

The aim of this paper is to present the results of the Middle Jurassic carbonate petrophysical analysis from a wide range of wells data gathered from the numerous petroleum wells drilled in the PICOREF Sector from 1953 to 2001 (Fig. 1).

More specifically, the carbonate sediments considered as potential reservoirs for hosting geological storage of $\mathrm{CO}_{2}$ in the studied area are from Upper Bathonian to Lower Callovian age. The lithostratigraphic units are, from bottom to top: the Oolithe Blanche oolithic Upper Bathonian limestone interlayed with the lagoonal Comblanchien limestone, and the Dalle Nacrée bioclastic limestone (Lower Callovian). As concerns $\mathrm{CO}_{2}$ storage, key issues are the storage capacity of the formations, the so-called "injectivity" of potential reservoir units, and the confining properties of less permeable (aquitard) units. Sedimentary heterogeneity at the formation scale and petrophysical parameters at the bed scale (porosity, permeability, and relative permeability, and capillary entry pressure for two-phase flow) are determinant features either for capacity, injectivity or confinement. They are inherited from both depositional context (facies distribution) and diagenesis.

\section{GEOLOGICAL SETTING}

The PICOREF Sector is located in the south-eastern part of the Paris Basin, in the Champagne area, at about one hundred kilometres north-westwards the Burgundy Middle Jurassic outcrops (Fig. 2). The whole sector is included in the large burgundian carbonated platform. This main physiographic feature extends from the French Channel coast to northern Jura.

\subsection{Stratigraphy}

The studied carbonate reservoir units are attributed to the upper part of the Middle Jurassic (Upper Bathonian to Lower
Callovian). The Middle Callovian overlying formation, known as the Marnes de Massingy inférieures, form the aquiclude of these underlying aquifers and aquitards.

\subsection{Sedimentology}

Owing to the tertiary tiliting of the south-eastern edge of the Paris Basin, the Middle Jurassic sedimentary succession outcrops in the Burgundy quarries. It is composed by the stacking of four carbonated platforms (Fig. 2) of unequal volume (Purser, 1967, 1989; Floquet et al., 1989; Gaumet et al., 1996; Gaumet 1997):

- the two Bajocian Platforms, separated by the thin marly open marine Marnes à Ostrea acuminata episode, the lower one is an entrochal limestone rich in reefal clasts, the upper one is an oolithic limestone;

- the burgundian Bathonian Platform (the thickest one), that lays directly on the upper bajocian platform of the sector, characterized by the final deposition of lagoonal inner shelf facies called Comblanchien formation protected by high energy facies (oolithic barriers) called Oolithe Blanche formation. These two main coeval formations are distinguished on sedimentological, diagenetic and petrophysical criteria;

- the thin residual Lower Callovian platform characterized by the deposition of neritic biocalcarenites and oozes, called the Dalle Nacrée, and covered by the continuous open marine marls, the Marnes de Massingy.

The producing oil-bearing reservoirs are located in the two upper formations: the Dalle Nacrée and the Comblanchien limestone formations.

The studied interval is restricted to the three uppermost carbonate formations, from base to top, the Oolithe Blanche (Upper Bathonian), the Comblanchien (Upper Bathonian) and the Dalle Nacrée (Lower Callovian). This is illustrated by a stratigraphic NW-SE cross section through the PICOREF Sector (Fig. 3, Houel, 2008).

As said before, the Middle Callovian Marnes de Massingy inférieures, about $20 \mathrm{~m}$ thick in the Sector, form the contiguous overlying seal of these reservoirs. The top of these marls is used as a regional marker bed called RIO (Repère Inférieur Oolithique). It is locally interpreted as condensed iron oolithic layer of Upper Callovian age (Collin, 1999, 2005).

\subsection{Hydrogeology}

To describe the hydrodynamic behaviour of the Middle Jurassic in the PICOREF Sector, several hydraulic units have been distinguished by Houel (2008) according to all the available logs giving a low resolution (metre-scale) profile of porosity:

- "aquifer" units present the best porosity values and are likely to include connected and permeable reservoir beds; 

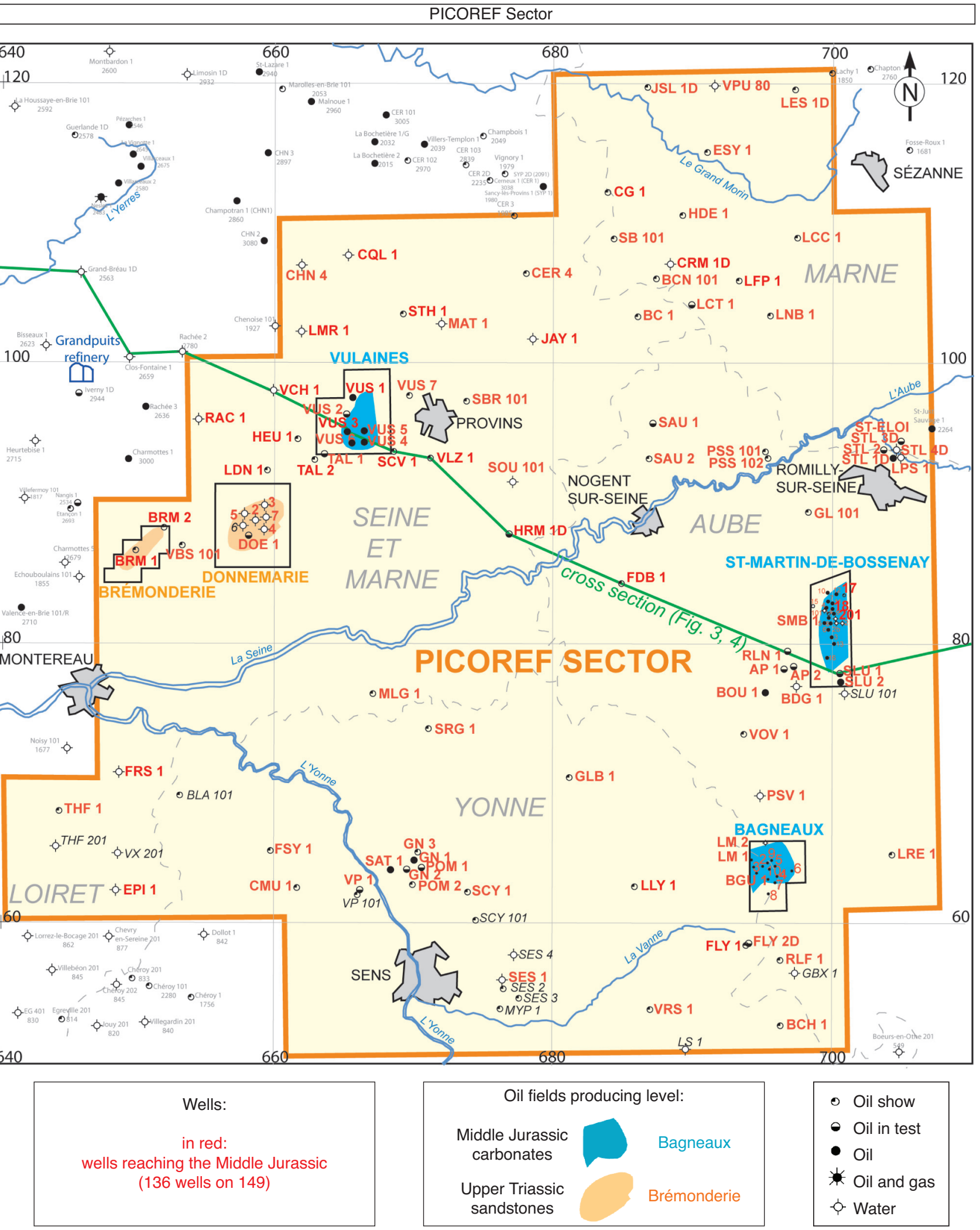

Figure 1

Location map of the petroleum wells drilled in the PICOREF Sector (1953-2001). Geographic coordinates are expressed in km (French Lambert I Zone). 


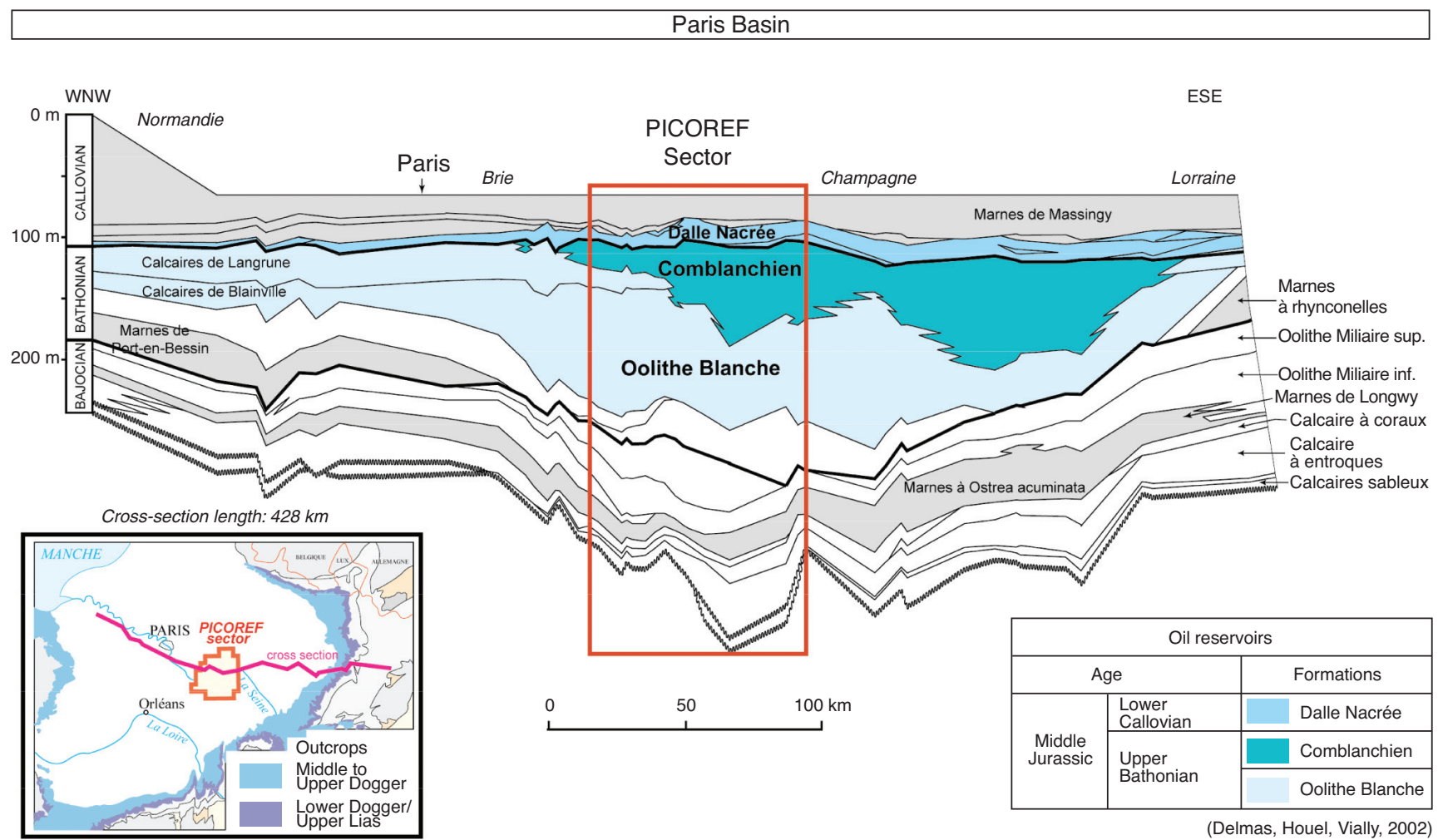

Figure 2

Lithostratigraphic cross-section through the middle to upper Middle Jurassic of the Paris Basin.

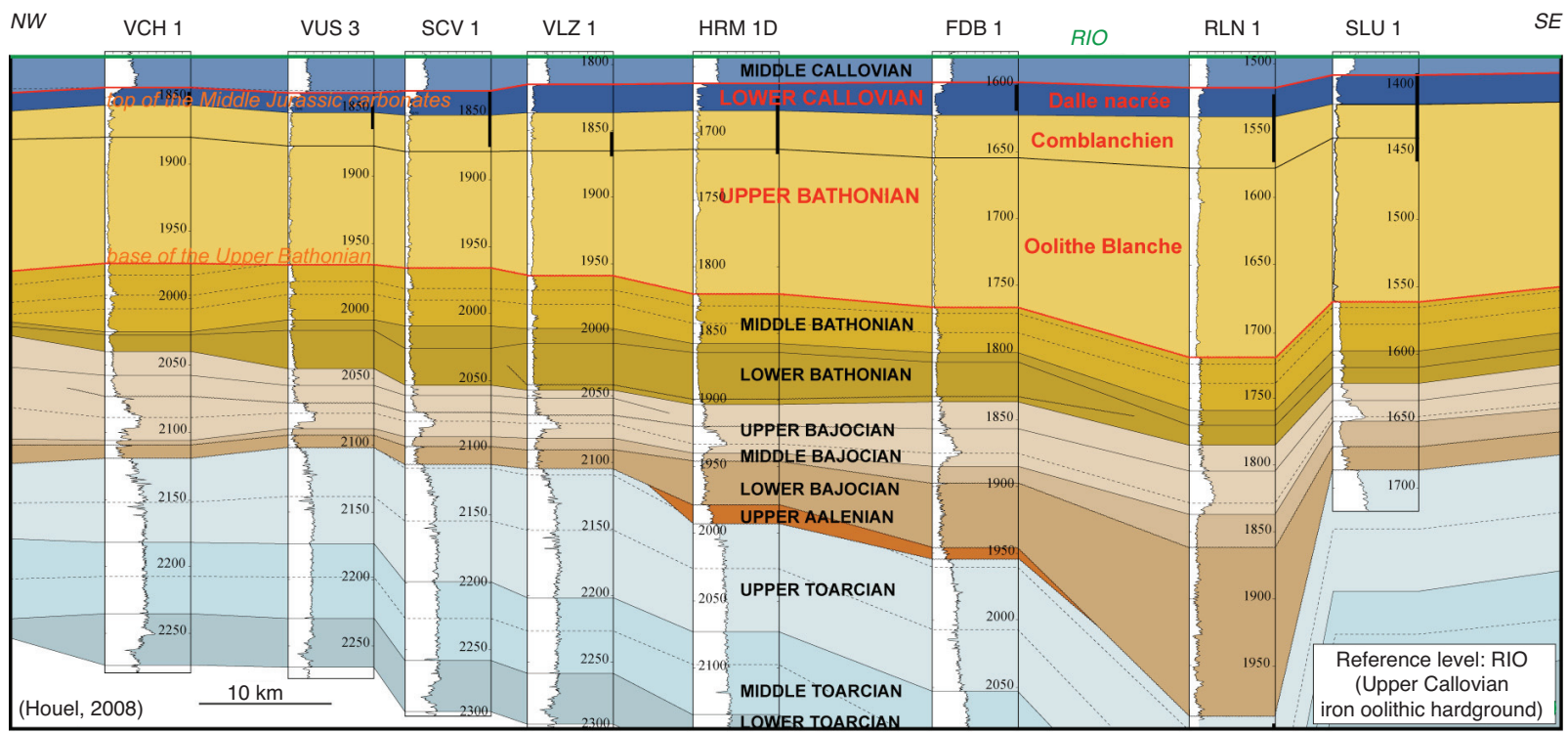

Figure 3

Middle Jurassic: NW-SE stratigraphic cross section through the PICOREF Sector (see location map, Fig. 1). Length: 64 km. Upper and lower boundaries of the studied interval are in red. 


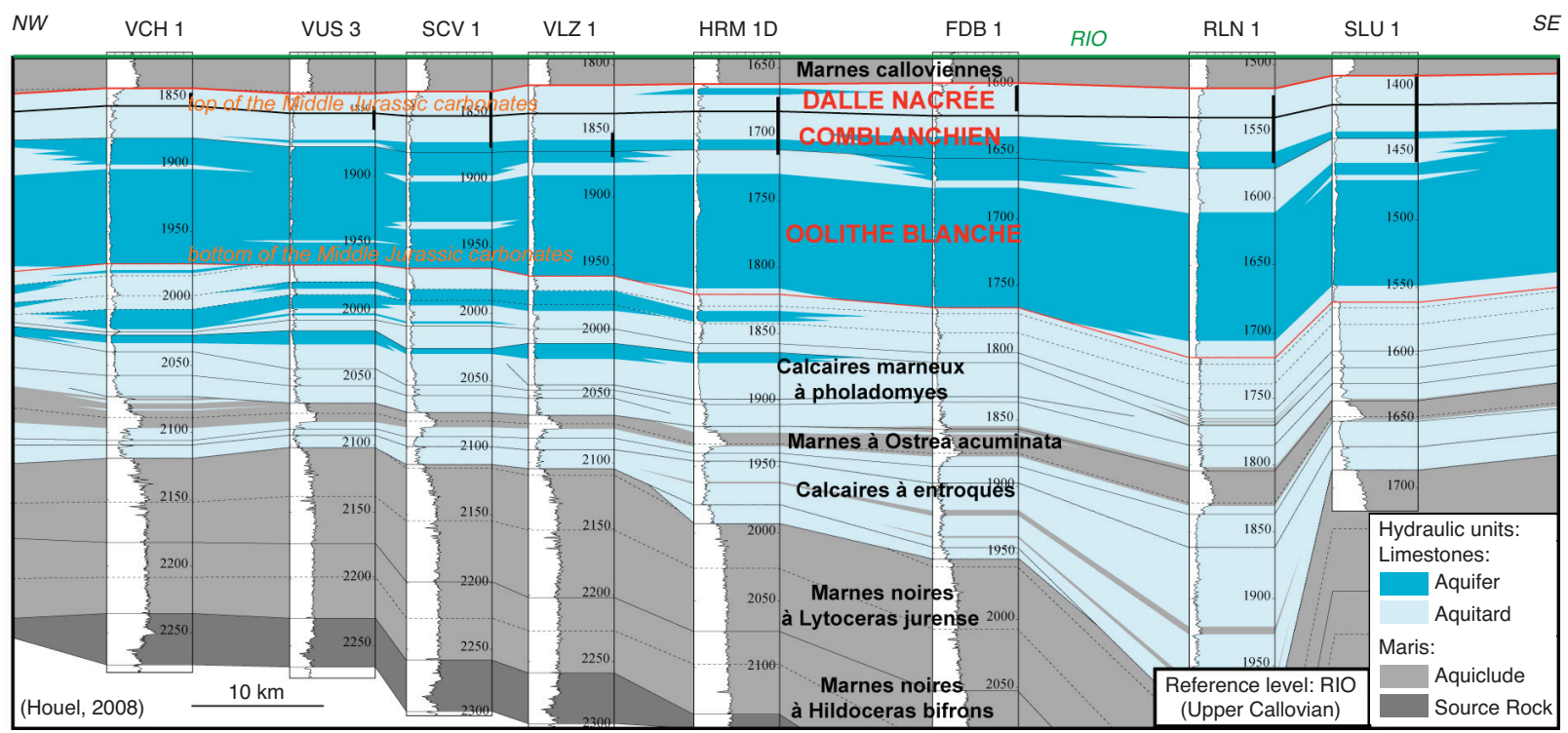

Figure 4

Middle Jurassic: NW-SE hydrogeological cross section in the PICOREF Sector (see location map, Fig. 1). Length: 64 km. The studied formations names and the interval boundaries are in red.

- "aquitard" units hydraulic properties are considered too poor for hosting $\mathrm{CO}_{2}$ as storage reservoirs;

- "aquicludes" are marly seals.

As shown by the hydrogeologic NW-SE cross section through the studied Sector (Fig. 4), the Oolithe Blanche formation constitutes the thickest aquifer unit of the studied series. The Comblanchien and the Dalle Nacrée formations contain both aquifer and aquitard alternating levels.

The description of the lithologic column is shown in the detailed log of the Saint-Martin-de-Bossenay SMB 17 well (Fig. 5).

\section{METHOD}

The characterization of the petrophysical properties of the three studied reservoirs units in the PICOREF Sector consisted in building a clean and exhaustive key petrophysical database that will be the basis for understanding the petrophysical properties of the carbonate beds considered as potential targets aquifer units for $\mathrm{CO}_{2}$ storage. The measured values of porosity, permeability, and density from core plug samples were gathered for this study and then digitized. The analysis of these numerous well data consisted in the following steps:

- plotting the petrophysical measures in function of the depth for the cored intervals of 75 wells (Delmas, 2006). The studied series is totally cored on the only well SaintMartin-de-Bossenay 1 (SMB 1);
- plotting the available core porosity and permeability values. The interpretation of the different scatters (Delmas, 2007) is made with the available textural data extracted from the summary core description sheet;

- characterizing the porous medium owing to the available Mercury Injection Capillary Pressures on the core samples of the reference SMB 1 well (Delmas, 2008);

- comparing the $\mathrm{CPI}^{(2)}$ porosity (ELAN software) computed from the few available dizitized wireline loggings (Renoux, 2007) with the core porosity values from the same number of wells;

- comparing the computed porosity with the drill cuttings porosity and permeability values (Lenormand, 2008) on the uncored interval for the Oolithe Blanche and Comblanchien units of the Fontenay-de-Bossery 1 well (FDB 1) to valid this new technical device.

The PICOREF Sector (Fig. 1) is included in a $70 \mathrm{~km} \times$ $70 \mathrm{~km}$ square, between the $0.6 \mathrm{E}$ gr. and $1.65 \mathrm{E}$ gr. meridians, and the $53.50 \mathrm{~N}$ gr. and $54.2 \mathrm{~N}$ gr. parallels. It extends on about $4000 \mathrm{~km}^{2}$, on four departments: Seine-et-Marne, Yonne, Aube, and Marne. The Seine river cuts the Sector along a wide NE-SW valley. The irregular shape of the Sector is due to the respect with 50000 scale geological maps grid. In total, 149 wells were drilled from 1953 to 2001 by fifteen different petroleum companies. The great majority of them (136) reached the top of the Middle Jurassic (Fig. 1,

(2) CPI: Computed Porosity Interpretation. 


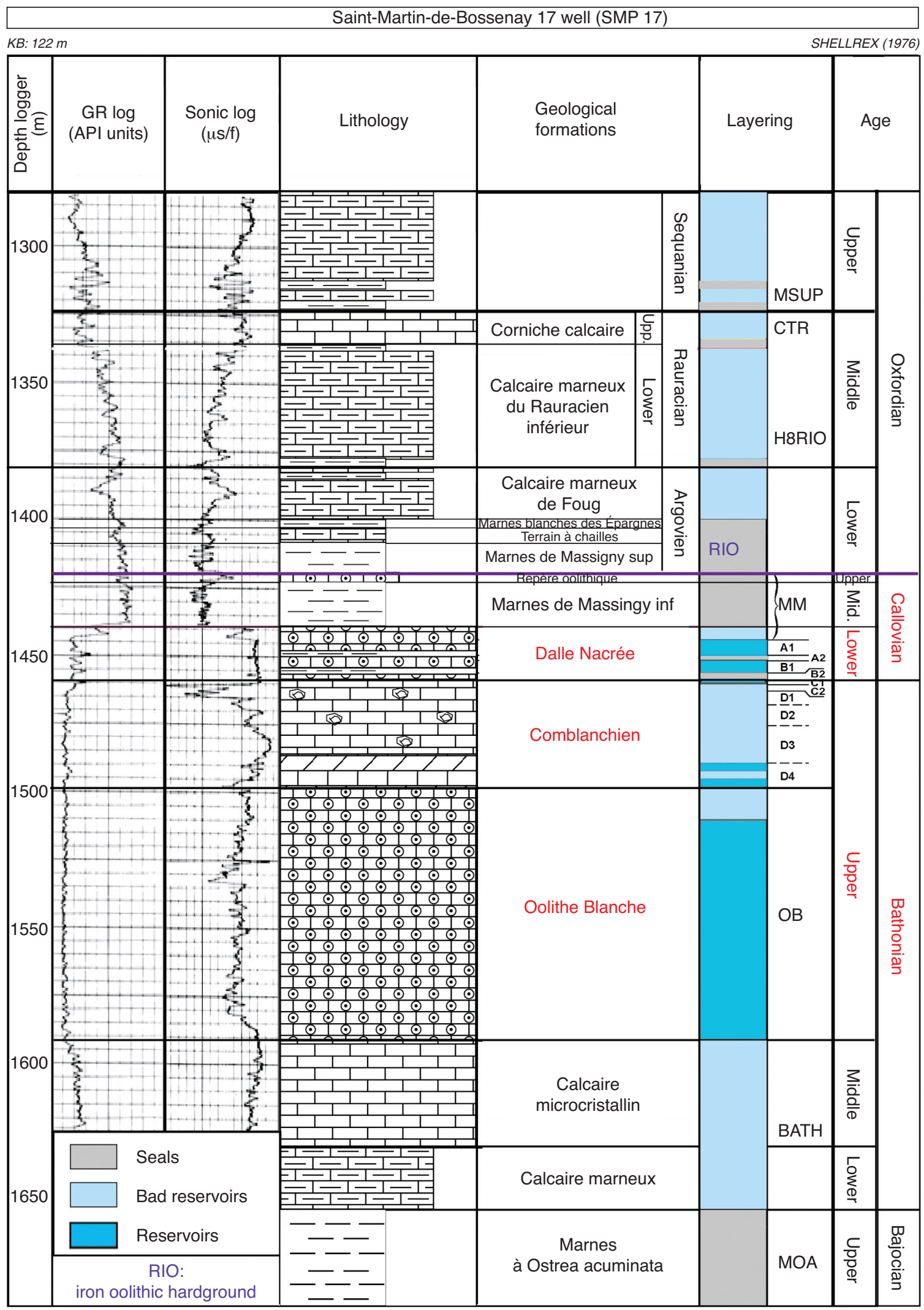

Figure 5

The Middle Jurassic reservoirs: SMB 17 well. 
Tab. IA in appendix). The inter-well spacing, related to the local oil exploration, is irregular, ranging from one to several kilometres.

\section{AVAILABLE DATA}

The Middle Jurassic was reached at altitudes ranging from $-1230 \mathrm{~m}$ to $-1750 \mathrm{~m}$. They got through the whole Dalle Nacrée formation. The Comblanchien series was totally bored by 83 wells, and the Oolithe Blanche by 54 wells (Fig. 6). The number of wells that core the totality of the three units strongly decreases from the top to the bottom: 100 wells for the Dalle Nacrée, 22 wells for the Comblanchien, but only one well for the Oolithe Blanche (SMB 1 well). This fact could be explained by the logic of oil exploration. The two upper units are potential oil reservoirs, and the lower one was bored only to reach the triassic objectives.

In total, 5800 metres of cores were taken in a hundred wells with a good recovery rate (90-100\%).

The available well data are the non-digitized logs, the core descriptions, the core measurements, and the well test results. All these data are very heterogeneous because of the long time span between the first and the last drilling (about fifty years), and because of the great number of companies (fifteen in total) that explored the Sector:

- the wireline logs set is more or less complete from well to well with only a Spontaneous Potential and a Resistivity for the oldest ones, unfortunately their digitized versions are not available;

- the available core descriptions, carried out during the coring by the well site geologist, are essentially lithological descriptions: the geologic information is generally basic,

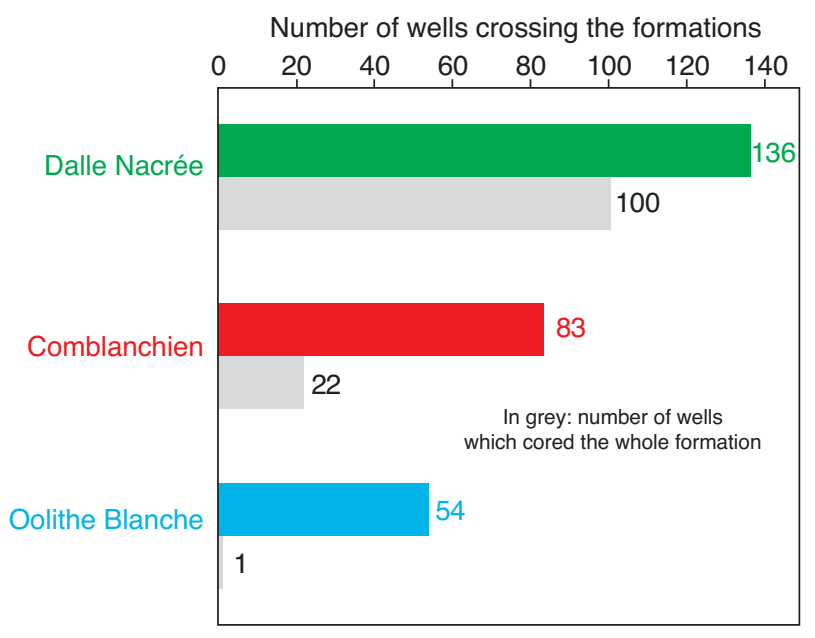

Figure 6

Number of wells crossing and coring the three studied formations. the textures and rock fabrics are frequently obsolete old description not systematically identified (no thin sections). Few core intervals were described with new conceptual notions (reinterpreted core descriptions in thesis, recent wells);

- the core measurements: more than 6000 values of routine core measurements: (porosity, permeability and density) on horizontal plugs, and one hundred special core measurements (mercury injection tests) were gathered from the available paper well reports, and then digitized for this study. Often, vertical plugs, parallel to the core axis, were acquired in order to check for possible anisotropy. The spacing of the plug sampling on lithified intervals is generally a foot-range is more or less high from well to well (three samples per meter of core). We can distinguish:

- routine core measurements: a total of 6872 porosity values and 6252 permeability values is available. Their number decreases from the top to the bottom of the studied series (Fig. 7);

- one hundred special core measurements made by mercury injection processes on the SMB 1 reference well (Marrast, 1960).

The injection pressure and the mercury saturation were determined graphically from the experimental capillary curves. The corresponding pore aperture radii were calculated using Laplace equation for thirteen capillary pressures $(2,3,5,10,20,30,40,50,70,100,150,200$, and $\left.250 \mathrm{~kg} / \mathrm{cm}^{2}\right)$;

- the flow tests. Numerous flow tests (drill stem tests, build-up tests) were carried out in the wells of the studied Sector: 127 in the Dalle Nacrée, 56 in the Comblanchien, but only 5 in the Oolithe Blanche. This procedure for testing the surrounding geological formation through the drill pipes allows to measure the formation pressure and to sample the formation fluid for analysis. But, generally, the tests interpretation (Horner straight line slope, permeability calculation) are not available in the well reports.

Core porosity: 6872 measurements

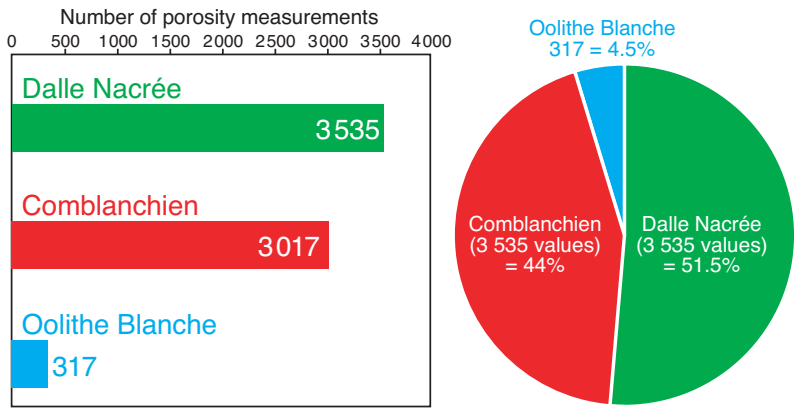

Figure 7

Distribution of the available core porosity data for the three studied formations. 


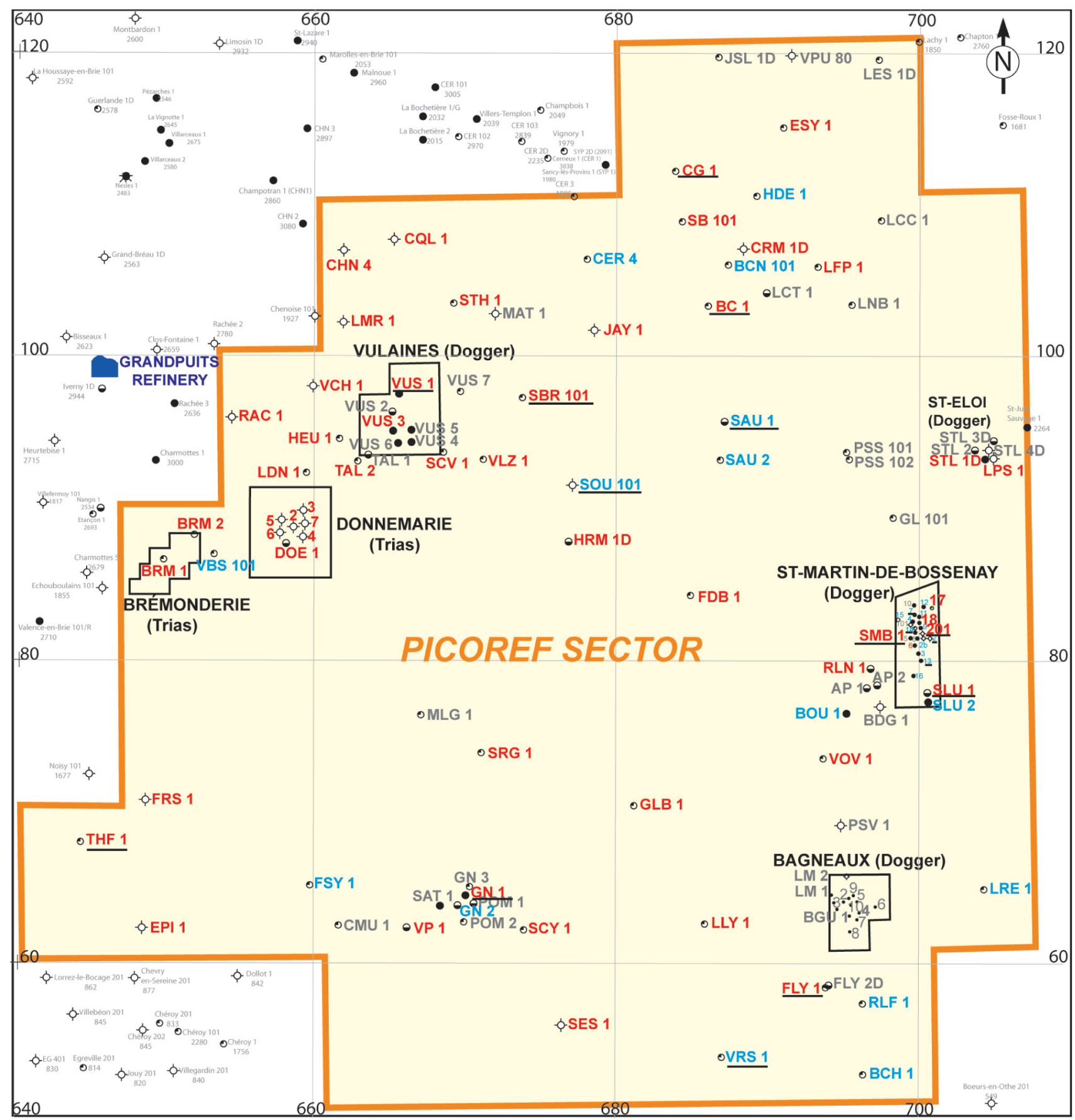

\section{Petroleum wells:}

136 wells reaching the Middle Jurassic 81 wells reaching the Oolithe Blanche 54 wells crossing the whole Oolithe Blanche 19 underlined wells: Oolithe Blanche partly cored (only one well cored the whole Oolithe Blanche: SMB 1)
Middle Jurassic oils fields

Saint-Martin-de-Bossenay

Bagneaux

Saint-Éloi

Vulaines

- Oil show
- Oil in test
- Oil
Oil and gas
- Water

- Oil show

- Oi - - - Water

Figure 8

Oolithe Blanche: wells location map. 


\subsection{Data Available on the Oolithe Blanche Formation}

Reached by 81 wells in the PICOREF Sector (Fig. 8), the Oolithe Blanche formation was totally crossed by 54 of them, partly cored on 18 wells, and fully cored on one reference well: SMB 1. As indicative, the total cored length is $337 \mathrm{~m}$.

Generally devoid of oil, the Oolithe Blanche formation was tested in only five wells at the beginning of the exploration (Fig. 9). Bouchy-le-Repos 1 is the only well in which tests and core intervals are matching. The scarcity of the tests explains this lack of adequacy.

To obtain a more representative population, the studied area was extented to the burgundian outcrops. The available 317 core data were measured on 13 wells: eight of them are located in the PICOREF Sector (Fig. 10a) and five in the Burgundy Block, between the Sector and the outcrops (Fig. 10b).

As special measures, fourteen Mercury Injection Tests were recovered for the twenty upper metres of the Oolithe Blanche in the Saint-Martin-de-Bossenay 1 reference well.

\subsection{Data Available on the Comblanchien Formation}

In the PICOREF Sector, the Comblanchien formation was:

- totally crossed by 83 wells, three quarter are partially cored, and the remaining one is totally cored;

- partially cored on 66 wells;

- totally cored on 22 of them.

The available values ( 3017 porosity and 2644 permeability) were measured on the cores of 51 wells in the Sector (Fig. 11a) and 9 wells close to the Sector (Fig. 11b). But only $15 \%$ of the wells were properly sampled (with more than 100 samples each). The outer wells are less influential than in the Oolithe Blanche population. We keep them to be coherent.

A broad population of sixty-six mercury injection tests were retrieved from the Comblanchien units in the SaintMartin-de-Bossenay 1 well.

Fifty-six well tests were performed in the Comblanchien formation with a great number in front of cored section.

\subsection{Data Available on the Dalle Nacrée Formation}

In the PICOREF Sector, the Dalle Nacrée formation has been bored by 136 petroleum wells; one hundred of them cored this formation.

The 3538 available porosity values and the 3313 permeability values were measured on 57 wells drilled in the studied Sector (Fig. 12a) and 16 close to it, in the Burgundy Block (Fig. 12b).

Thinner than the Comblanchian, only twenty mercury injection tests were carried out from the Dalle Nacrée units in the Saint-Martin-de-Bossenay 1 reference well.
One hundred and twenty-seven well tests were performed in the Dalle Nacrée formation.

\section{RESULTS}

The petrophysical characteristics of each formation, deduced from the available data listed above, are examined in this section. Due to its completeness, the reference SMB 1 well was choosen as the reference borehole. The well chart shows a multilayered reservoir architecture with few compact inter-reservoir. Several porous and permeable units can be distinguished from top to base (Fig. 5, 13):

- two thin A and B reservoir levels separated by marly interval in the Dalle Nacrée formation;

- a very thin $\mathrm{C}$ reservoir unit at the top of the Comblanchien Fm, separated from the Dalle Nacrée by a marly interval (Marnes à digonelles);

- a thick heterogeneous alternating D unit spanning all the Comblanchien under a cemented compact upper layer;

- the thick massive Oolithe Blanche Fm reservoir which is an aquifer in the PICOREF Sector, but it yields locally oil in the Coulommes-Vaucourtois oil field, at $30 \mathrm{~km} \mathrm{NW}$ from the Sector.

Commonly, carbonate rocks exhibit a wide variety of petrophysical properties that reflects their diverse depositional and diagenetic fabrics (Rafavich et al., 1984; Lucia, 1995). This assertion makes any prediction of reservoir quality without a clear identification of the facies and their burial history a difficult challenge. We will try to solve some of these puzzling questions with the data already gathered despite their present inadaquacy.

\subsection{Petrophysical Properties of the Oolithe Blanche Formation}

\subsubsection{Description}

About 70-80 meters thick in the studied area, the Upper Bathonian Oolithe Blanche limestone is called Calcaire de Chamesson along in the North Burgundy outcrops. It is composed of shallow marine oolithic limestones varying from grainstones to packstones. The oolithic sandbars are deposited in a wave and tide-dominated environment spreading in peripheral high-energy areas of the burgundian platform.

\subsubsection{Petrophysical Properties}

The porosity of the Oolithe Blanche ranges from 1 to $26.8 \%$, and the average value is $14.5 \%$, the mode $18 \%$ (Fig. 14a), and the median value $14.3 \%$.

Typically, the permeability, measured on 292 horizontal plugs, is very low, ranging from 0.1 to $2 \mathrm{mD}$ (Fig. 14b). 


\begin{tabular}{|c|c|c|c|c|c|c|c|c|c|c|c|c|c|c|c|c|c|c|c|}
\hline $\begin{array}{l}\overline{0} \\
0 \\
0 \\
0\end{array}$ & $\underset{0}{\overline{0}}$ & & & $\begin{array}{l}\bar{g} \\
\overline{0}\end{array}$ & 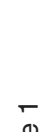 & $\begin{array}{l}\overline{0} \\
\stackrel{\oplus}{\subseteq} \\
.0\end{array}$ & $\bar{c}$ & 흠 & $\bar{\sigma}$ & & Saint & artir & de-E & sser & & & $\begin{array}{l}\bar{\infty} \\
\Phi \\
0\end{array}$ & 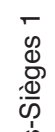 & \\
\hline 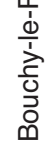 & 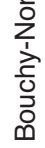 & 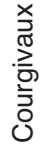 & $\begin{array}{l}\overline{\text { Jे }} \\
\frac{\pi}{4}\end{array}$ & 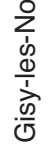 & 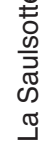 & 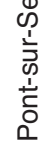 & 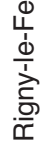 & 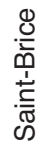 & 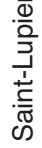 & $\bar{\infty}$ & $\sum_{\infty}^{N}$ & $\sum_{\omega}^{\mathfrak{m}}$ & $\sum_{\infty}^{\frac{m}{m}}$ & $\frac{\nabla}{\sum_{\infty}^{\infty}}$ & $\begin{array}{l}\bar{N} \\
\dddot{\infty}\end{array}$ & $\begin{array}{l}\text { 으 } \\
\text { ㄷ } \\
\text { 음 }\end{array}$ & 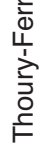 & 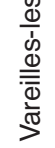 & $\begin{array}{l}\bar{\infty} \\
\stackrel{\Phi}{\frac{\pi}{\sigma}} \\
\frac{\bar{\sigma}}{5}\end{array}$ \\
\hline
\end{tabular}
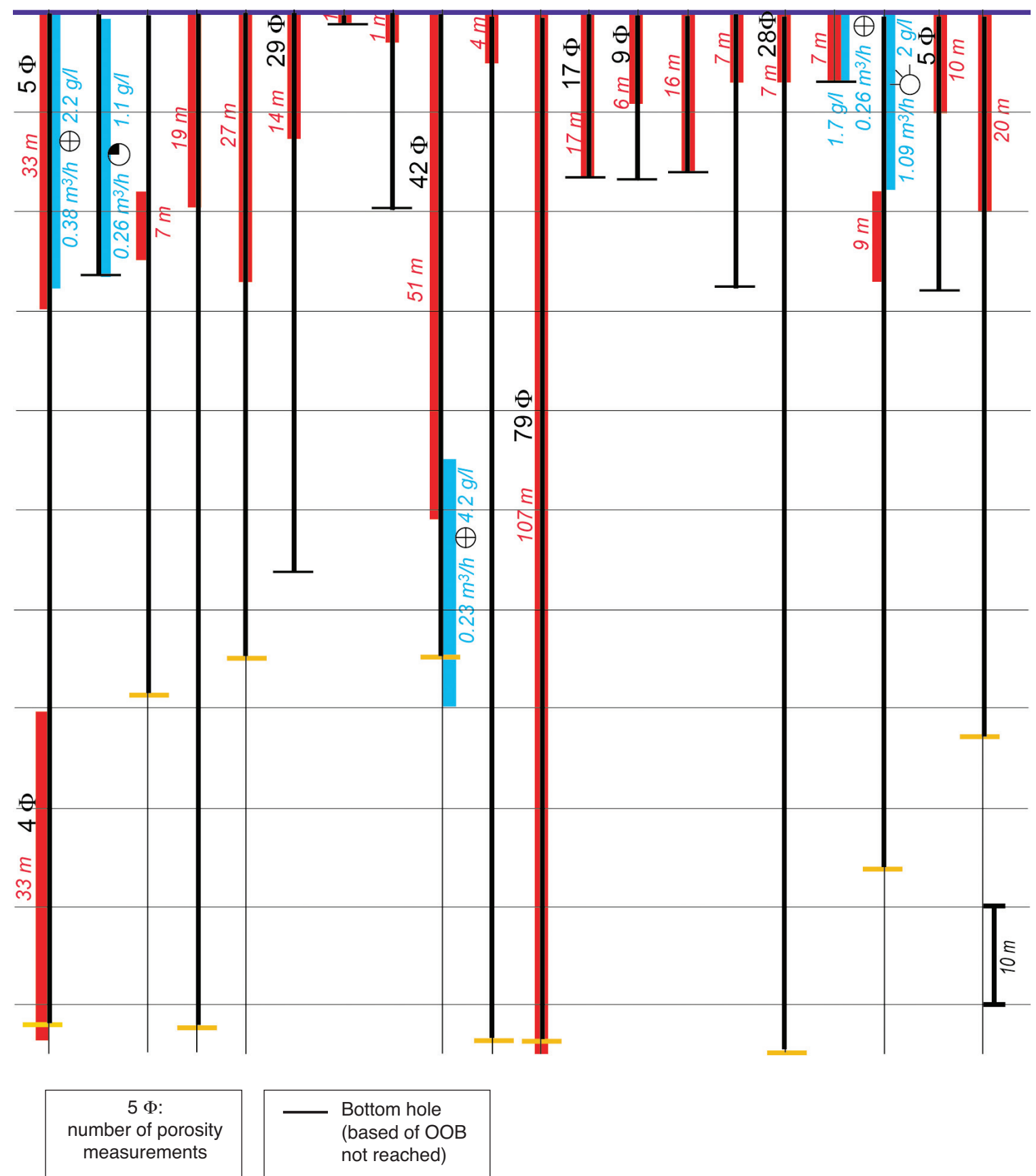

Figure 9

Oolithe Blanche: cored and tested intervals on twenty wells of the PICOREF Sector. 

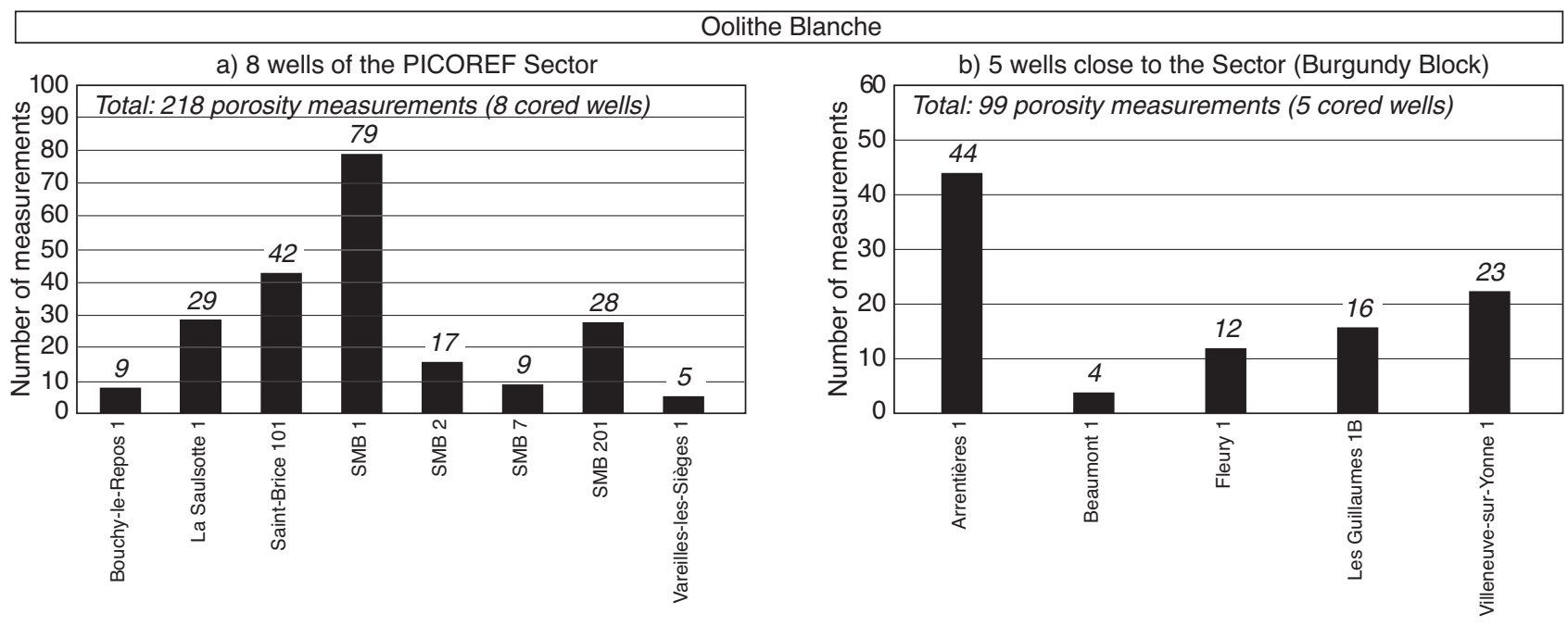

Figure 10

Oolithe Blanche: number of available core measurements from eight wells of the PICOREF Sector a), and five wells of the Bloc bourguignon $\mathrm{b})$.

The Oolithe Blanche limestones are relatively isotropic at the sample scale (Fig. 14b) as shown by the comparison between the horizontal and vertical permeability values measured on 152 plugs (7 wells).

To compare with the wirelog responses, we present the result of the ELAN software computing made by P. Renoux on the Fontenay-de-Bossery 1 well where the average porosity of the uncored Oolithe Blanche interval is around $15.5 \%$ (Fig. 15b). The reason of the choice of this well is explained later in this chapter.

\subsubsection{Porosity - Permeability Cross-Plot}

The porosity - air permeability cross-plot (Fig. 16a) shows a large scatter (295 points from 13 wells) stretching along the porosity axis with low permeability values (less than $10 \mathrm{mD}$ ) with a concentration of the permeability values under $10 \mathrm{mD}$. The rock fabric attribution (Fig. 16b) is deduced from the core descriptions available for only ten wells.

Whatever the carbonate sediment fabric, and despite high porosity, the permeability is low. In fact, porosity is here restricted in the micrite of both matrix and grains, and this micro-porosity is not enough connected to provide good permeability. The occurence of primary intergranular porosity (grainstone) does not seem to explain this distribution. The porosity is probably related to particles isolated in cement or matrix.

\subsubsection{Porosity and Pore-Throat Radius Distribution (After Mercury Injection Tests)}

Eight samples were selected among the 79 ones available in the Oolithe Blanche of the SMB 1 well (Fig. 17a). The eight distribution curves (Fig. 17b) show that pore-throats size is lower than $1 \mu \mathrm{m}$. The typical low permeability values (0.3-1.5 mD) of the sample are due to the absence of macro-connected porosity, that confirms the previous petrography-derived interpretation.

In the case of the SMB 1 well, the acquisition protocol followed during mercury injection in the sixties was not sufficiently strict fine (only fifteen automatic stages) to calculate the derivative of the capillary pressure curves and to obtain a distribution of equivalent pore threshold radii. So, recent measurements made by the IFP laboratory (Lombard, 2007) on eight samples of the Oolithe Blanche from two quarries located in the Burgundy outcrop at Ravières and Massangis (Yonne) are presented (Fig. 18). Showing one pore family, the modal value of the pore-throat radius being about 0.3-0.4 $\mu \mathrm{m}$, that confirms the previous results.

\subsubsection{Log/Drill Cuttings Porosity Comparison}

When cores are not available as it usually happens, the drill cuttings can provide quick and useful information for reservoir characterization. This method was applied to 17 drill cuttings sampled every ten metres, with a size diameter around $0.5 \mathrm{~mm}$ from the Oolithe Blanche and the Comblanchien carbonates (interval 1622-1766 m) in the Fontenay-de-Bossenay 1 well (Lenormand, 2008). On the other side, as said before, the porosity of this interval was computed by Renoux (2007) with the available wireline loggings. The frequency of log numerical sampling adopted by the user was very high: about five samples per metre (for a total of 984 values). The results obtained by the two methods were plotted together along the three formations intervals (Fig. 19). Their comparison shows that:

- the overall shape of the two obtained curves is analogous; 
Comblanchien

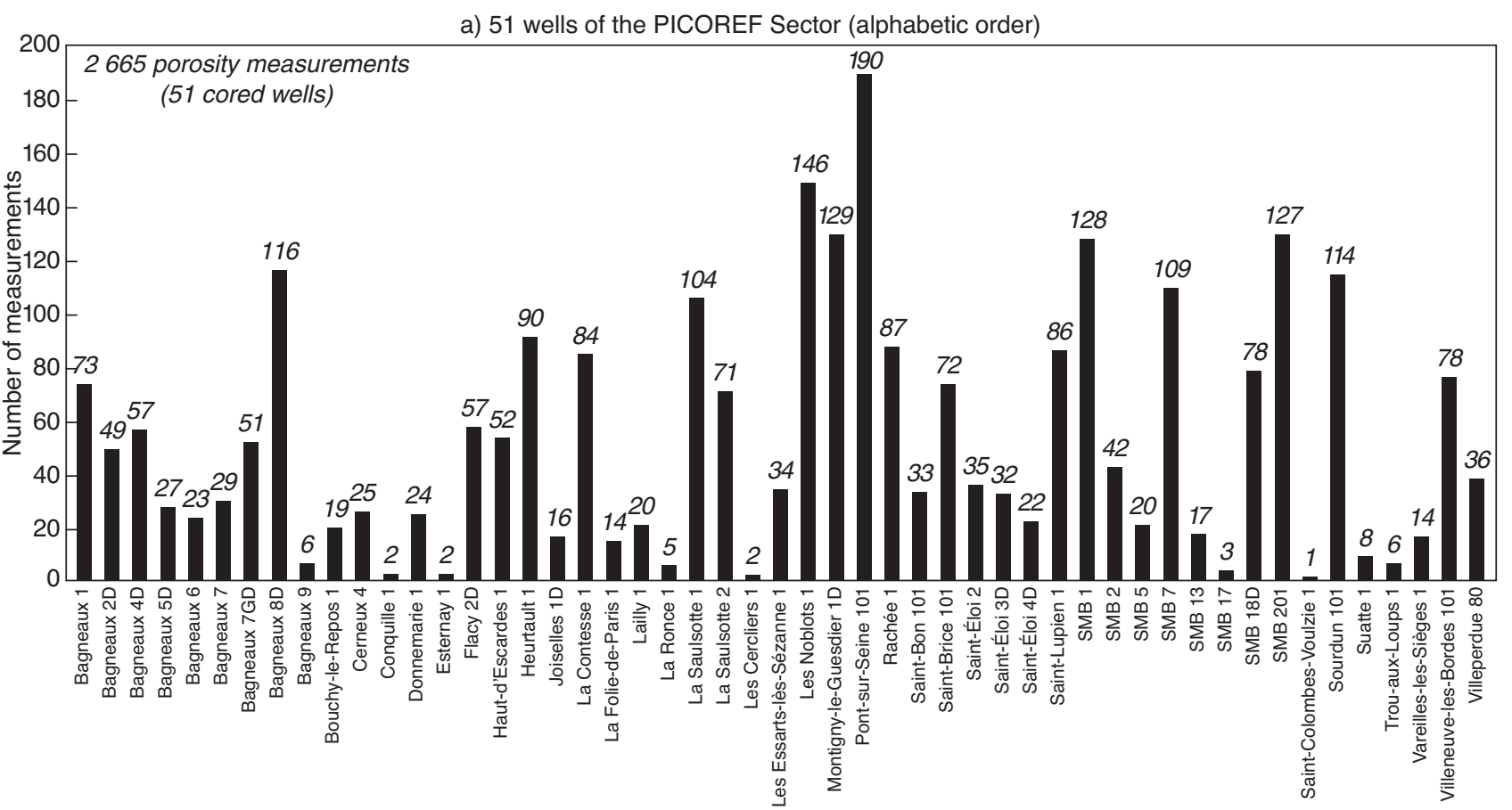

b) 9 wells close to the PICOREF Sector (Burgundy Block)
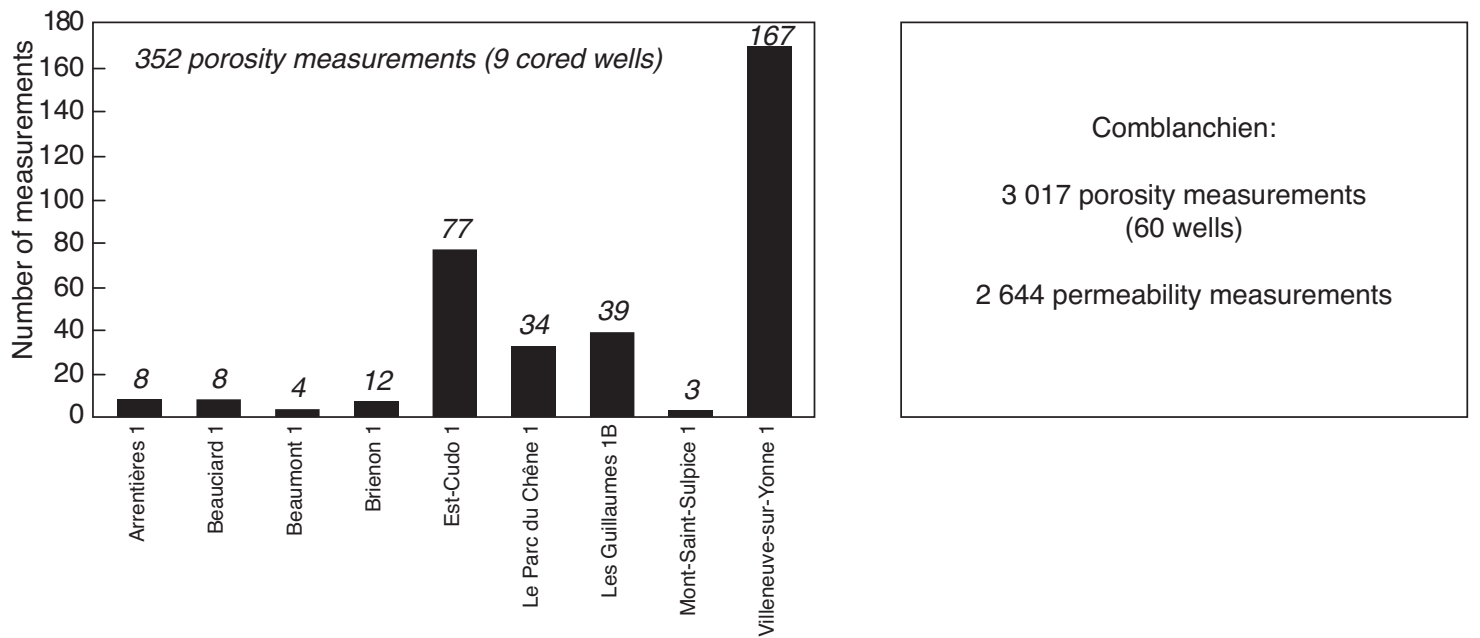

Figure 11

Comblanchien: number of available core measurements from 51 wells drilled in the PICOREF Sector a) and 9 wells close to the PICOREF Sector b).

- the measured porosity from cuttings is about 8 to $10 \%$ higher in value than the computed one.

This shift occurs with the two kinds of limestones. So its origin is probably related to measuring process.

The permeability, measured on the same cuttings with a new process developed by IFP, is very low (lower than
$0.1 \mathrm{mD}$ ). This process is based on the diffusion of a pressure wave in a viscous liquid saturating the cuttings.

\subsubsection{Flow Tests Results}

The flow rate measured in front of the Oolithe Blanche limestone formation is low: 0.23 to $0.38 \mathrm{~m}^{3} / \mathrm{h}$, with a maximum of $1.09 \mathrm{~m}^{3} / \mathrm{h}$. 


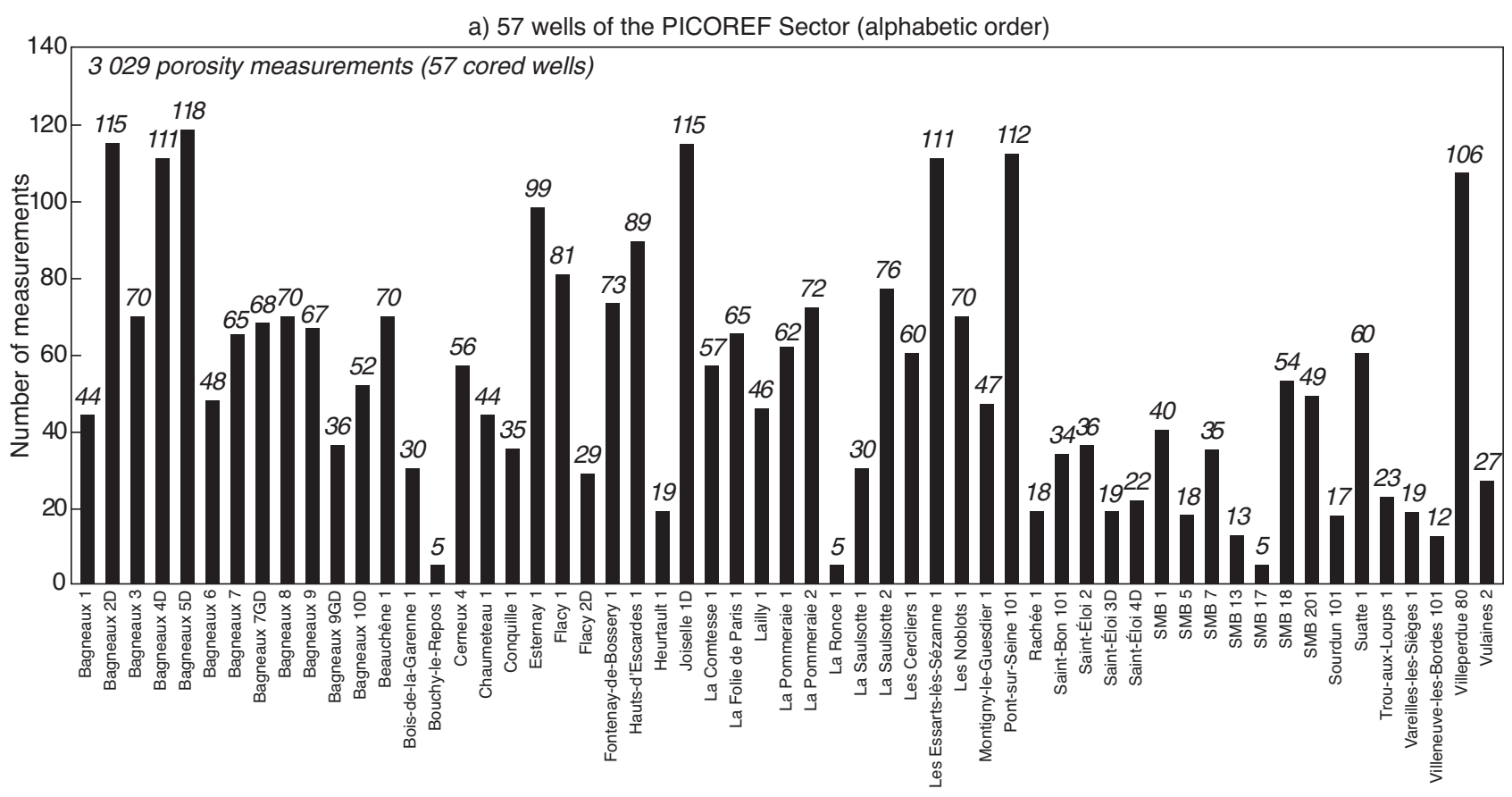

b) 16 wells close to the Sector (Burgundy Block)

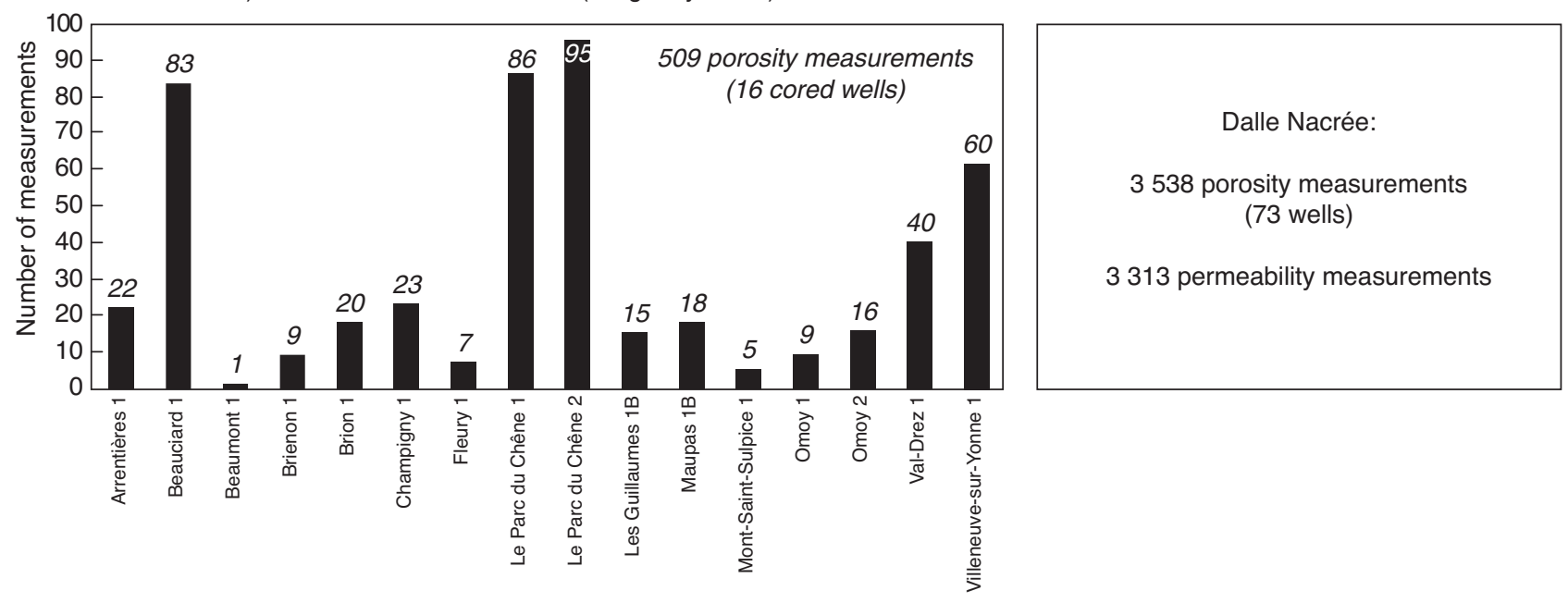

Figure 12

Dalle Nacrée: number of available core measurements from 57 wells drilled in the PICOREF Sector a) and 16 wells close to the PICOREF Sector b).

\subsection{Comblanchien Limestone}

\subsubsection{Description}

Fifty to sixty metres thick in the PICOREF Sector, the Upper Bathonian Comblanchien limestone formation is called Calcaire de Châtillon along the Burgundy outcrops. It is one of the most famous carbonate formations of the Middle
Jurassic in the Paris Basin. Oncoïds-rich, the Comblanchien (Floquet et al., 1989; Javaux, 1992; Garcia et al., 1996) consists of muddy facies (mudstones and wackestones, Fig. 20a) deposited in a protected lagoonal environment, some packstone-grainstone shoreface facies are locally interlayered (Fig. 20b). The muddy sublithographic limestones (lime oozes) are stylolitized (Fig. 20c) or microfissured (Fig. 20d). 


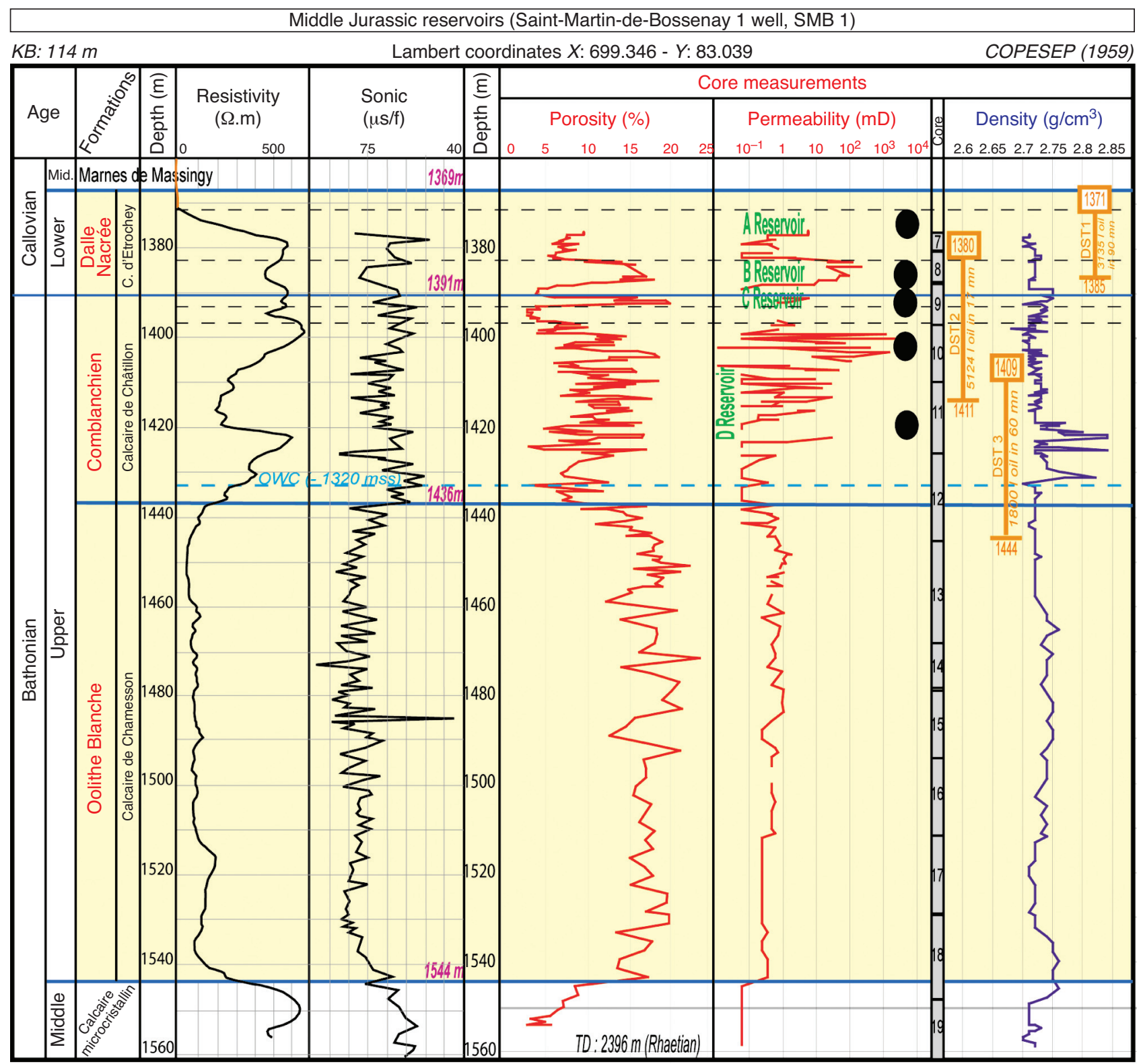

Figure 13

Saint-Martin-de-Bossenay 1 reference well chart.

The partial (or total) dolomitization observed by Clémence et al. (2005), and by Caspard et al. (2006) on the burgundian outcrops and on the Saint-Martin-de-Bossenay field cores (Fig. 21) can be linked either to emersions at the top of the Comblanchien sequences, or to the palaeo water level. The dolomitization is progressive affecting progressively matrix then grains. The early cemented top of the Comblanchien, calcitic in the SMB 1 well (Fig. 13), is characterized by a bioturbated and perforated surface.

The Comblanchien formation contains a thick reservoir $(40 \mathrm{~m})$, called "D" in the Saint-Martin-de-Bossenay field, separated from the overlying " $\mathrm{C}$ " reservoir (the two upper meters of the formation). This tight micritic limestone (Fig. 13 and Fig. 5), 4-5 m thick is the inter-reservoir layer separating the thick D reservoir from the overlying thin $\mathrm{C}$ reservoir layer as displays in Figure 13 on SMB 1 reference well chart.

\subsubsection{Petrophysical Properties}

The greatest core measured porosity of the Comblanchien can reach $22 \%$, but the average value is around $6 \%$. The frequency diagram (Fig. 22a) shows an unimodal distribution with a mode of $2 \%$ and a median of $4 \%$. The permeability is very variable from 0.01 to $3800 \mathrm{mD}$. The Comblanchien 


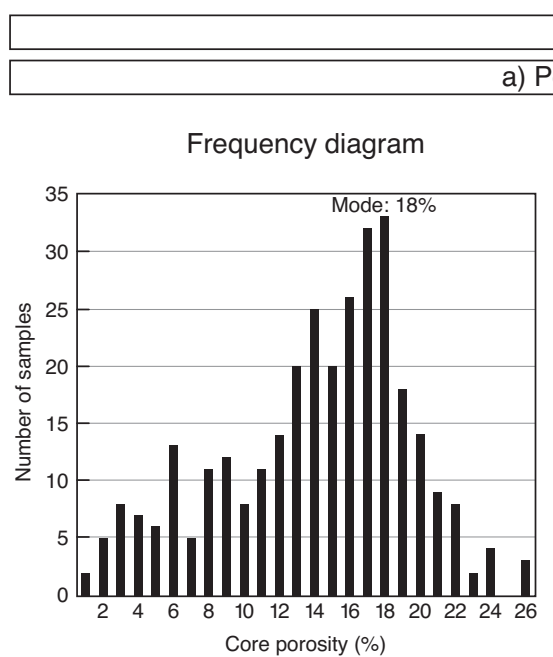

\section{Oolithe Blanche}

a) Porosity

Frequency cumulative curve

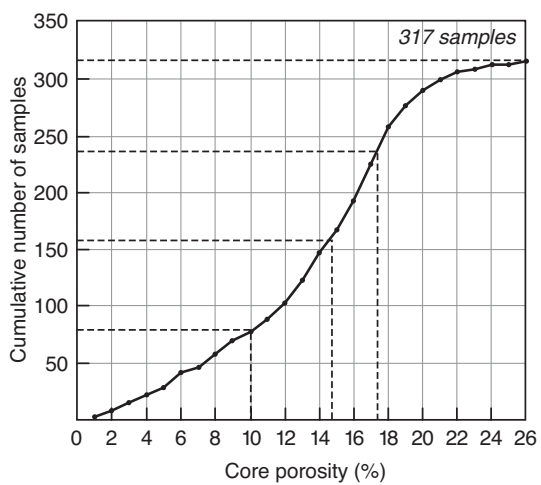

b) Permeability

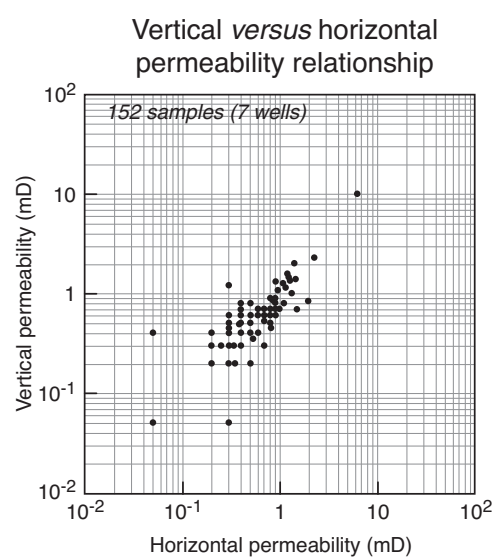

Figure 14

Oolithe Blanche: porosity a) and permeability b) core measurements.

carbonates are relatively isotropic at the sample scale (Fig. 22b) as shown by the comparison between the horizontal and vertical permeability values measured on 769 samples from 31 wells. This isotropy disappears at greater scale as shown by the fluctuations of the porosity and permeability curves in Figure 13.

\subsubsection{Porosity - Permeability Cross-Plot}

The porosity - air permeability cross-plot shows a wide scatter (Fig. 23a). Petrophysical properties of the Comblanchien carbonates were interpreted with respect of:

- the rock fabrics: grainstone, packstone, wackestone, mudstone (Fig. 23b);

- the mineralogy: limestones, dolomitic limestones (Fig. 25).

The rock fabric attribution (Fig. 23b), deduced from the available descriptions, shows that most of the available samples $(80 \%)$ with a mudstone texture, have very low permeability values (lower than $10 \mathrm{mD}$ and frequently much lower), whereas the porosity spans uniformly from $0 \%$ to $24 \%$ (Fig. 23): this is characteristic of microporous limestones. The subsidiary textures present better permeability values $(10 \mathrm{mD}$ to $1000 \mathrm{mD})$. The higher permeabilities measured in some mud dominated fabrics (wackestone-packstone) are probably due to the associated occurence of microfissures or stylolithes.

The four detailed porosity-permeability cross-plots by texture (Fig. 24) show that:

- the grain-dominated fabrics, the grainstones (Fig. 24a) can be divided into two categories according to the intensity of the cementation:

- residual intergranular porosity is observed on the grainstone plot (population I) while this population is absent in matrix fabrics,
- the population II is the result of filling of the pore-throat by cementation;

- the behaviour of the matrix-dominated fabrics (packstone to mudstone) are different: the three plots (Fig. 24b-d) show the same distribution with a numerous population of poorly connected microporosity, stretched along the porosity axis and a scarce population of stylolithised or microfissured samples. The similarity between the packstone and the mudstone plots suggests that the particles are not effective to explain the distributions. The cause of this is probably in the matrix, even if its percentage is low in packstones.

The available bulk matrix density measured systematically on 2644 core samples was used to differentiate the pure calcitic samples (density: $2.71 \mathrm{~g} / \mathrm{cm}^{3}$ ) from those enriched in dolomite (density higher than $2.71 \mathrm{~g} / \mathrm{cm}^{3}$ ). The resulting porosity - permeability cross-plot (Fig. 25) shows that the two lithologies have comparable petrophysical properties and that diffuse dolomitization does not improve reservoir properties in our case study.

\subsubsection{Porosity and Pore-Throat Radius Relationships (Mercury Injection Tests on the SMB 1 Well)}

Nine samples were selected among the 128 available ones (Fig. 25a) in the two reservoirs units (C and D) and in the interval between these two reservoirs (see SMB 1 well chart Fig. 13). The porosity versus pore-throat radius curves (Fig. 26b) show that:

- the porous granular carbonates of the D reservoir grainstones have either an unimodal or a bimodal threshold distribution:

- the samples No. 6 and 8 (grainstones), have exclusively a micro-connected porosity and a low permeability $(<1 \mathrm{mD})$. They show a pore-throat distribution which is 


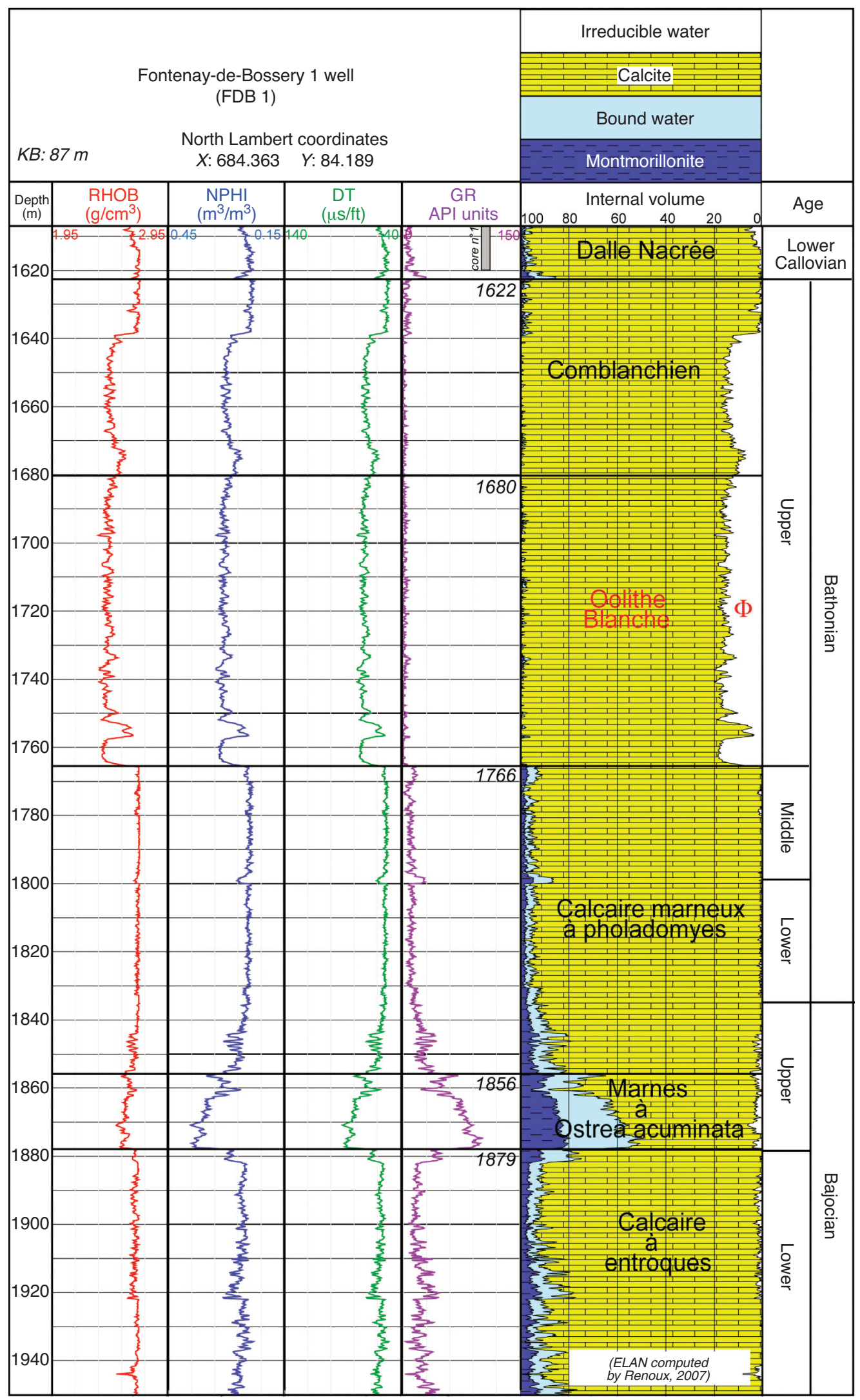

Figure 15

Oolithe Blanche: depth plot and computed porosity (Renoux, 2007) of the FDB 1 well. 

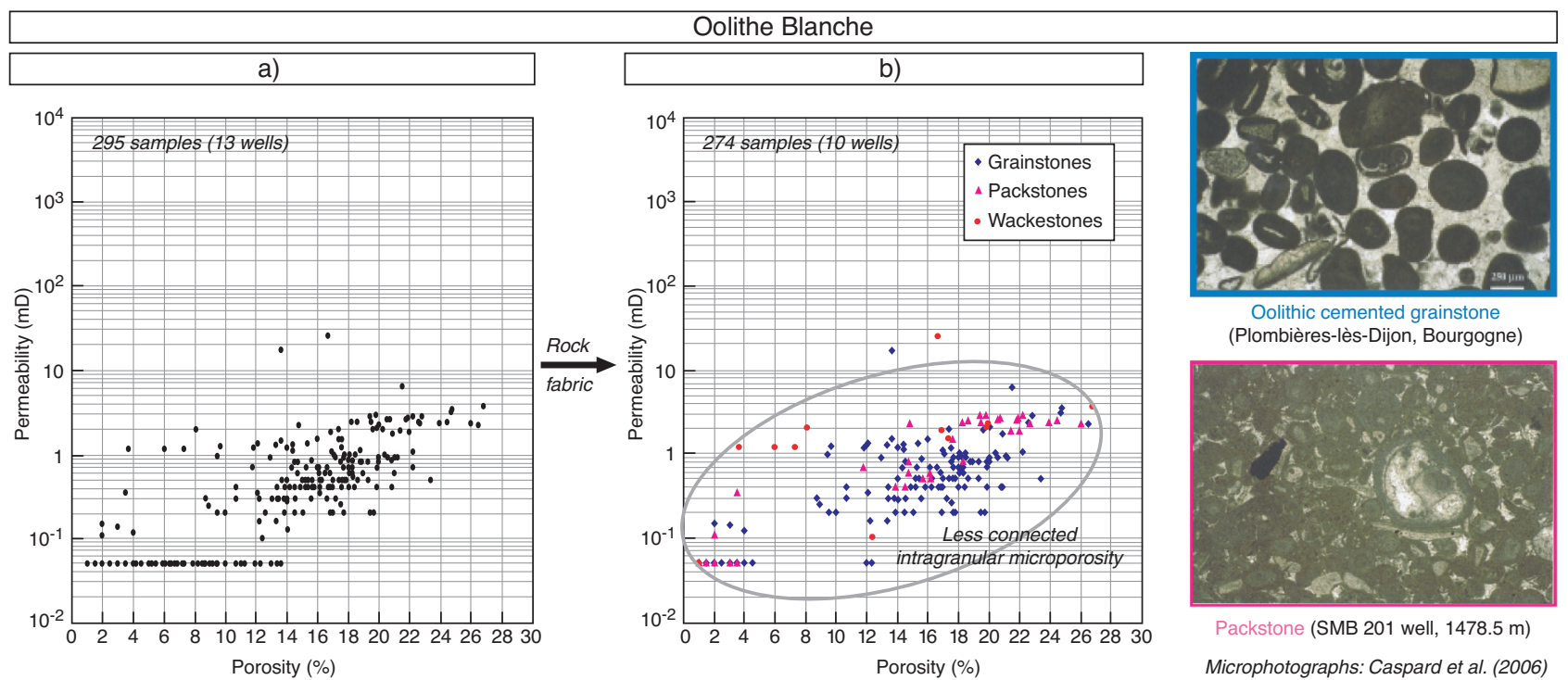

(Plombières-lès-Dijon, Bourgogne)

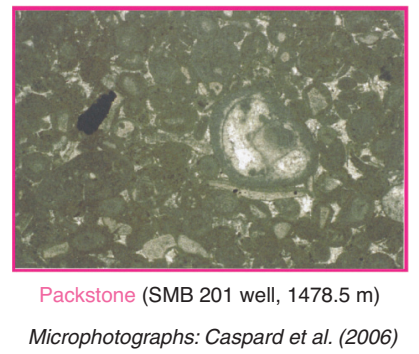

Figure 16

Oolithe Blanche: porosity - air permeability cross-plot a), textural interpretation b) and thin sections illustration of the main facies.

\begin{tabular}{|c|c|}
\hline & Oolithe Blanche \\
\hline a) & b) \\
\hline
\end{tabular}
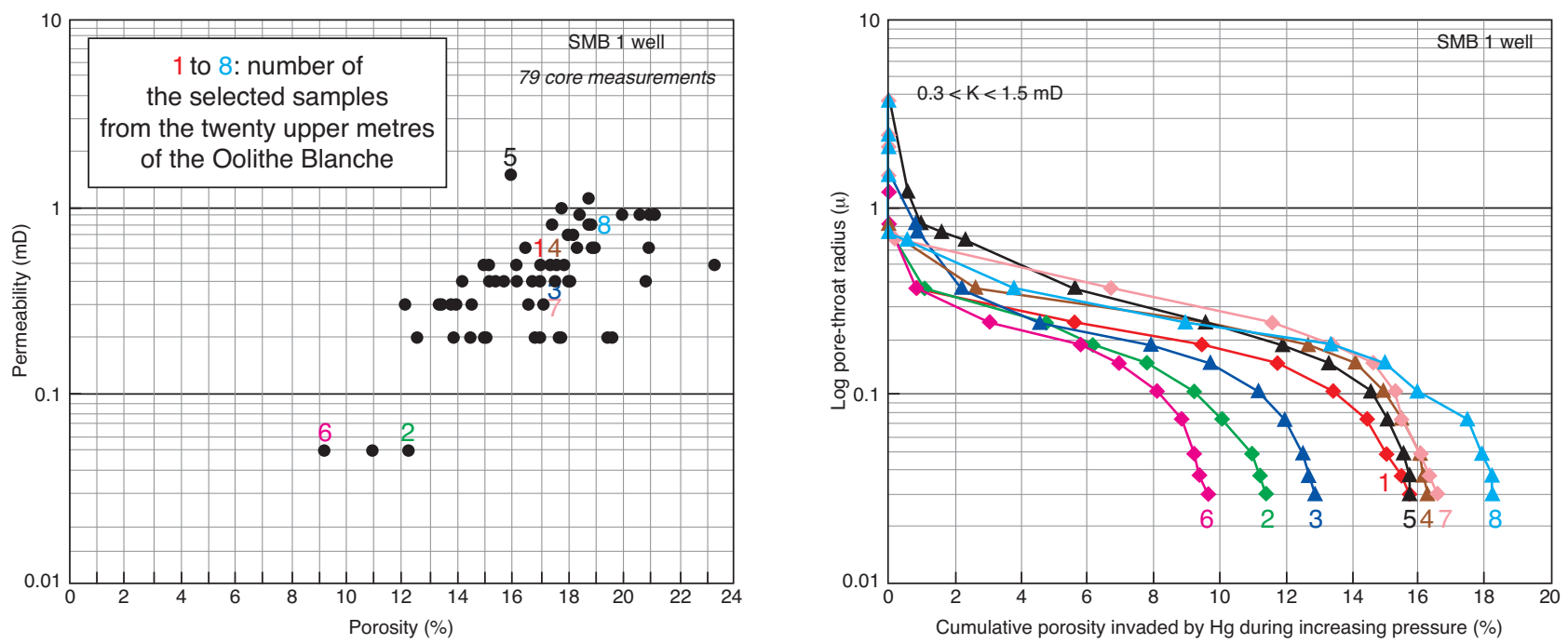

Figure 17

Oolithe Blanche (SMB 1 well): selection of eight measured samples a) used for plotting the pore-throat radius and the porosity b).

close to that of oolithic grainstones studied from Oolithe Blanche (Fig. 17b). The intergranualr pore space is probably cemented,

- the samples No. 4 and 5 have both a micro - and a macro - connected porosity. The micropore related throat radius is lower than 0.2 micrometer, and lower than the radius of micropore throats of samples No. 6 and 8 . The cement has probably filled the pore-throats;
- the micritic limestones (samples No. 2 of the C-D interval, and samples No. 7 and 9 of the D reservoir) have exclusively a micro-connected porosity with extremely small pore-throat radius (lower than 0.1 micron), and their permeability is very low (lower than $0.1 \mathrm{mD}$ );

- the No. 1 sample (C reservoir) seems to be abnormal. Indeed, despite the macro-connected porosity, the permeability is very low $(1 \mathrm{mD})$. It could be a sample with large 

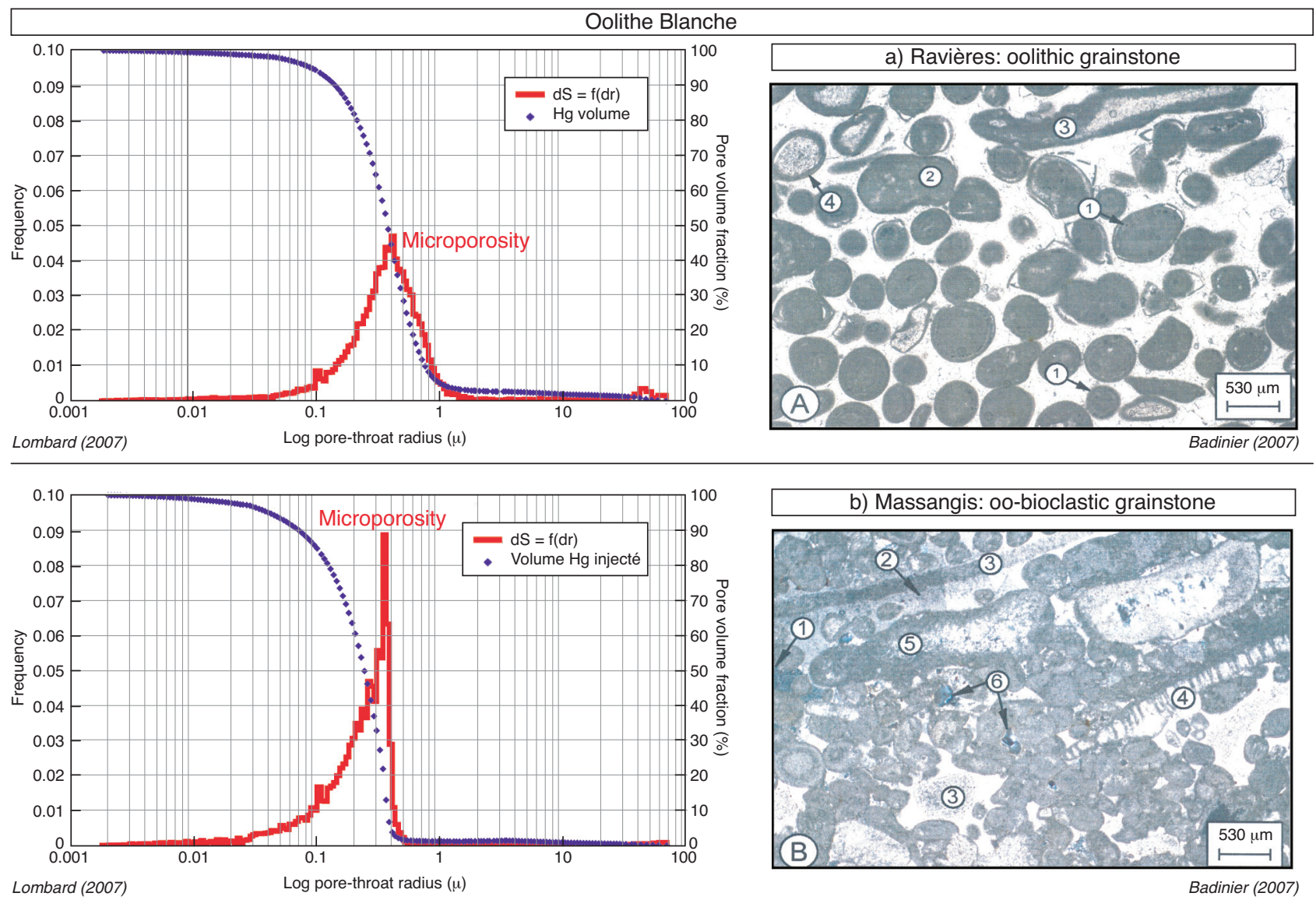

Figure 18

Oolithe Blanche (Burgundy): two examples of pore-throat size distribution plots and cumulative diagrams from mercury capillary pressure curves in two calcareous samples (grainstones) from the quarries of Ravières a) and Massangis b).

moldic macropores invaded by mercury at highest displacement pressures whereas no microporosity is naturally present to allow a connection between molds. Such a fabric could explain the low permeability.

\subsubsection{Flow Tests Results}

The flow rates measured on the Comblanchien carbonates are generally low: 0.01 to $3.8 \mathrm{~m}^{3} / \mathrm{h}$ (41 values), but it is locally higher $\left(12\right.$ to $14 \mathrm{~m}^{3} / \mathrm{h}$ ) for example in the Gisy-les-Nobles 3 and Saint-Martin-de-Bossenay 17 wells.

\subsection{Dalle Nacrée}

\subsubsection{Description}

About 10-28 m thick in the PICOREF Sector, the Lower Callovian Dalle Nacrée is called Calcaire d'Etrochey in the Burgundy region. It is mainly composed of shallow marine

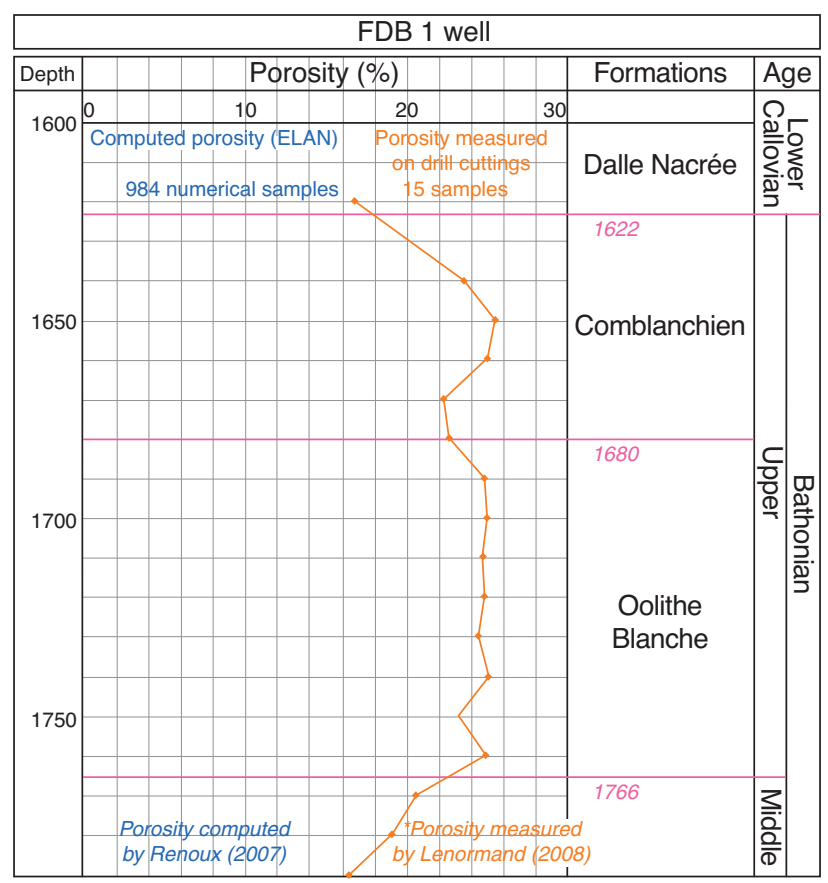

Figure 19

Middle Jurassic carbonates: depth plot of the computed porosity and the drill cuttings measured porosity (FDB 1 well). 

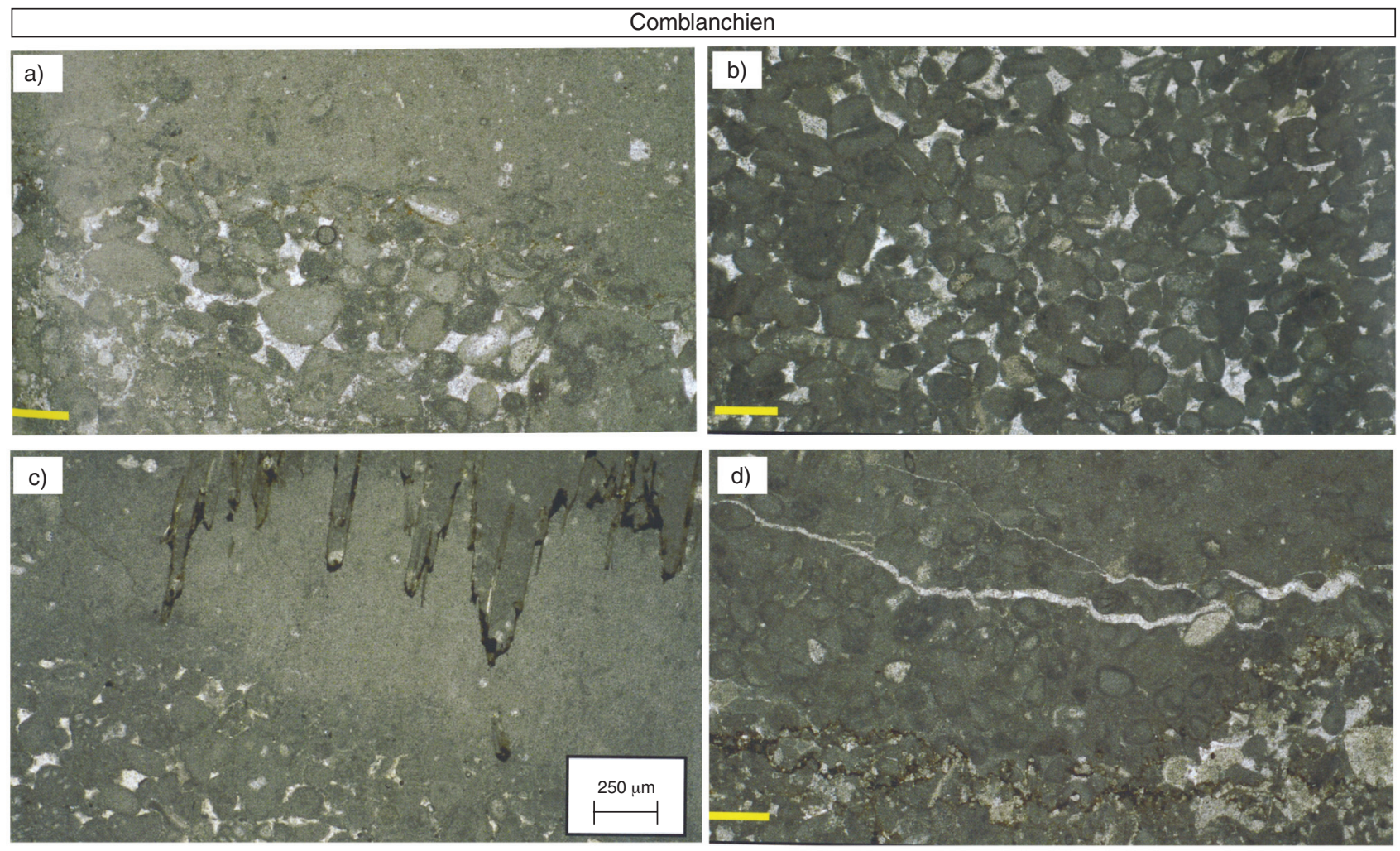

Figure 20

Comblanchien limestone facies (thin sections). a) Transition between micritic and granular facies (SMB 17 well), b) peloïdal packstonegrainstone (SMB 17 well), c) stylolith filled with insoluble clay (SMB 18 well) in the micritic limestones, d) cemented fissures (SMB 17 well).
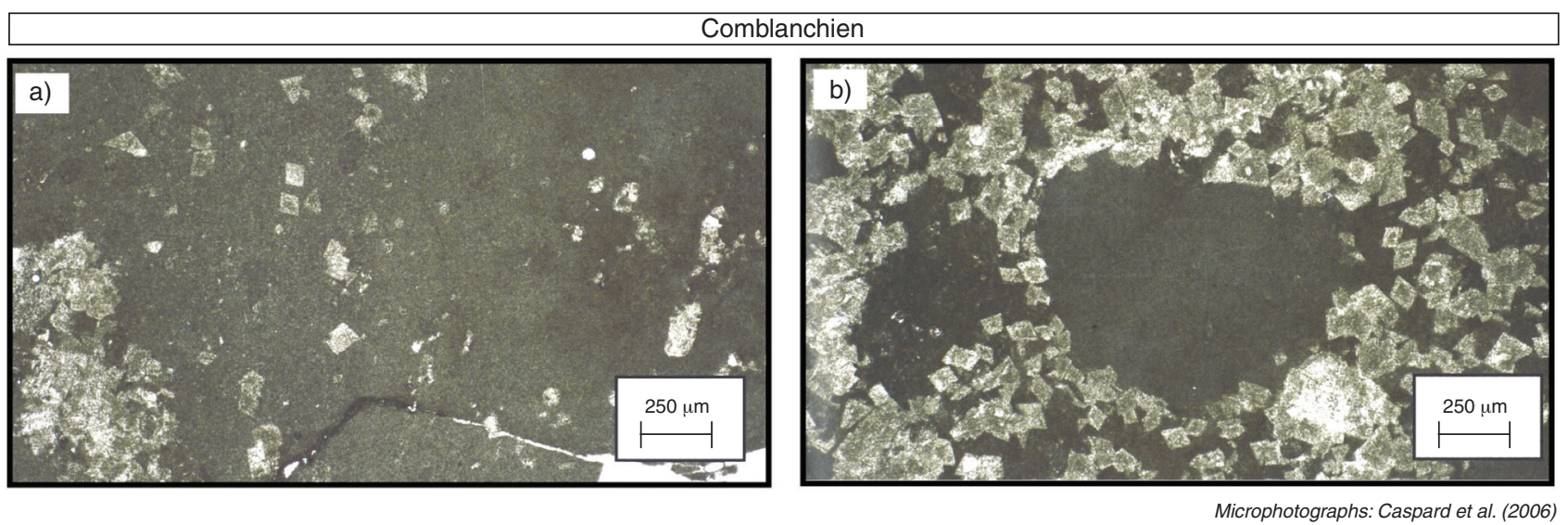

Figure 21

Comblanchien limestone facies: two examples of dolomitization in thin sections of the SMB 201 well. a) $1455 \mathrm{~m}$ depth, b) $1454.8 \mathrm{~m}$ depth.

oolithic and bioclastic limestones (oolithics sandbars, inner ramp). It consists of two main carbonate parasequences separated by a marly level named Marnes à digonelles (Fig. 27) studied by Floquet et al. (1989) on the Burgundy outcrops:
- the lower parasequence (Pierre de Dijon-Corton), deposited during a transgressive phase (Garcia et al., 1996; Gaumet et al., 1996; Gaumet, 1997), is subdivided into several depositionnal sequences interrupted by discontinuities of 


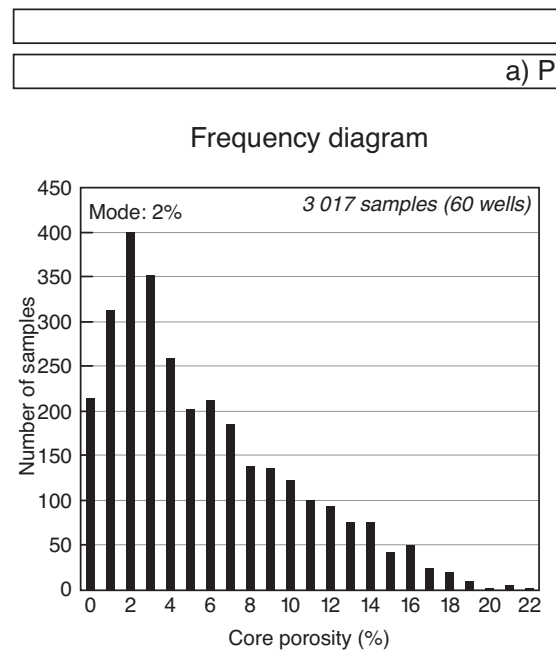

\section{Comblanchien}

) Porosity

Frequency cumulative curve

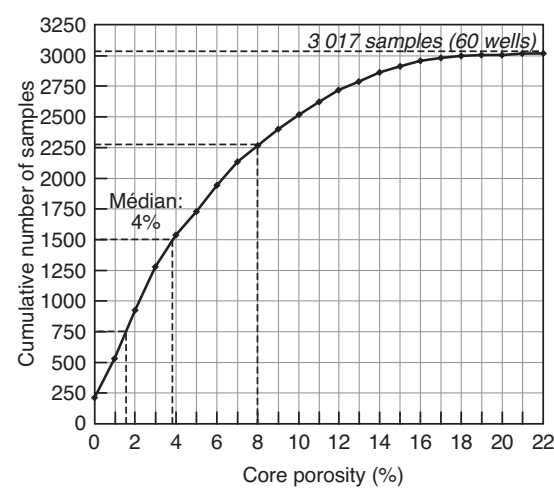

b) Permeability

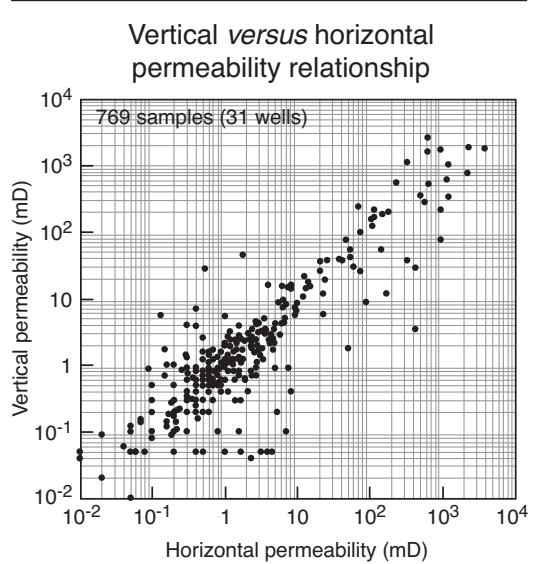

Figure 22

Comblanchien: porosity a) and permeability b) core measurements.
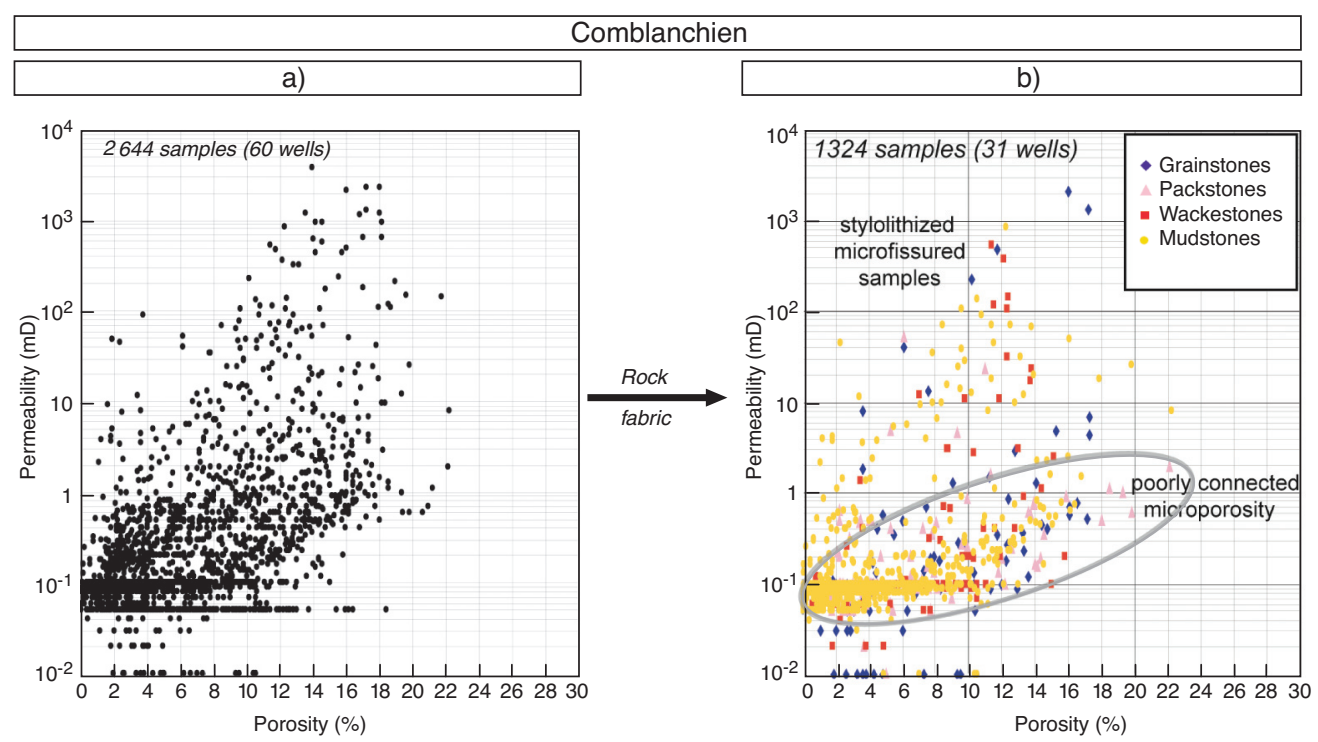

Figure 23

Comblanchien limestone: porosity - air permeability cross-plot a), and textural interpretation b).

regional value. A complete sequence begins by deepening facies followed by quiet and marine-open environments facies, then by very shallow environments facies sometimes characterized by emersion phases. Most of the elementary sequences are incomplete, generally lacking even the initial deepening facies or final shallower facies, destroyed by erosion. This system locally contains a porous level called B reservoir (see SMB 1 reference well chart, Fig. 13). This level is absent in the BGU 2D well (Fig. 27);
- the upper system (Pierre de Ladoix) consists of sequences beginning with argillaceous micritic facies and ending with calcarenitic beds. They can be considered as the result of shallowing processes which led to the edification and migration of oolithic and bioclastic sand waves. It locally contains a porous unit called "A reservoir". The top is characterized by a stacking of several perforated surfaces.

This architecture occurs in the main Callovian oil fields of the Paris Basin (Granier, 1995). 


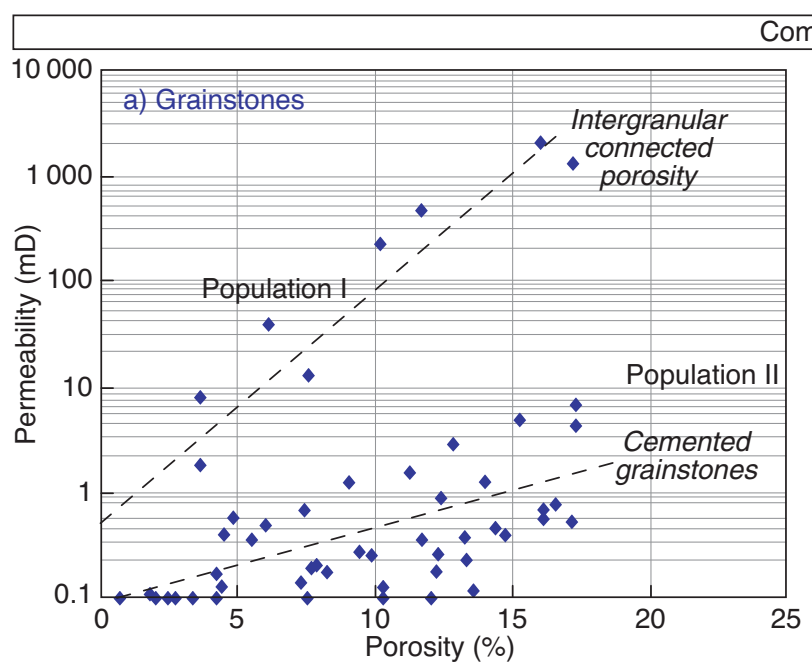

Comblanchien
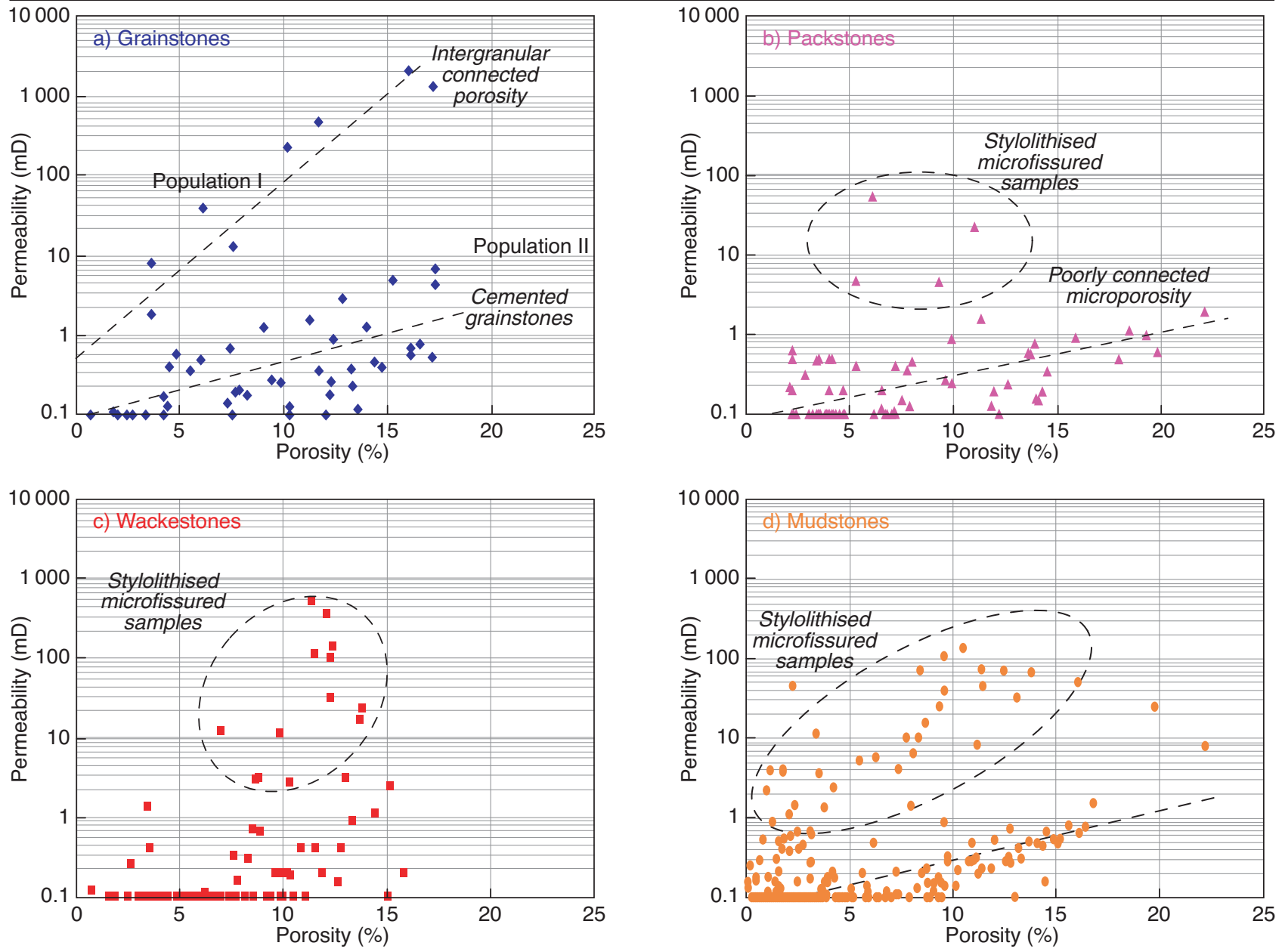

Figure 24

Comblanchien: porosity - air permeability cross-plots in function of the rock fabrics.

\subsubsection{Petrophysical Properties}

The porosity of the Dalle Nacrée formation can reach $19 \%$ in the "A" and "B" reservoirs with an average value of $5.5 \%$. The porosity distribution (Fig. 28a) is unimodal (mode: $3-4 \%$ ) with a median value of $2 \%$. The permeability ranges from $0.01 \mathrm{mD}$ to $1000 \mathrm{mD}$. The limestones are relatively isotropic at the sample scale whatever the facies (Fig. 28b) as shown by the comparison between the 330 available horizontal and vertical permeability values from 14 wells.

\subsubsection{Log/Core Porosity Comparison}

To confirm the reliability of the wireline logs response in this formation, a comparison between core and ELAN porosities was established for two wells: SMB 18 and FDB 1:

- for the SMB 18 well (Fig. 29), the log analysis is accurate despite a slight underestimation of computed porosity above $10 \%$;

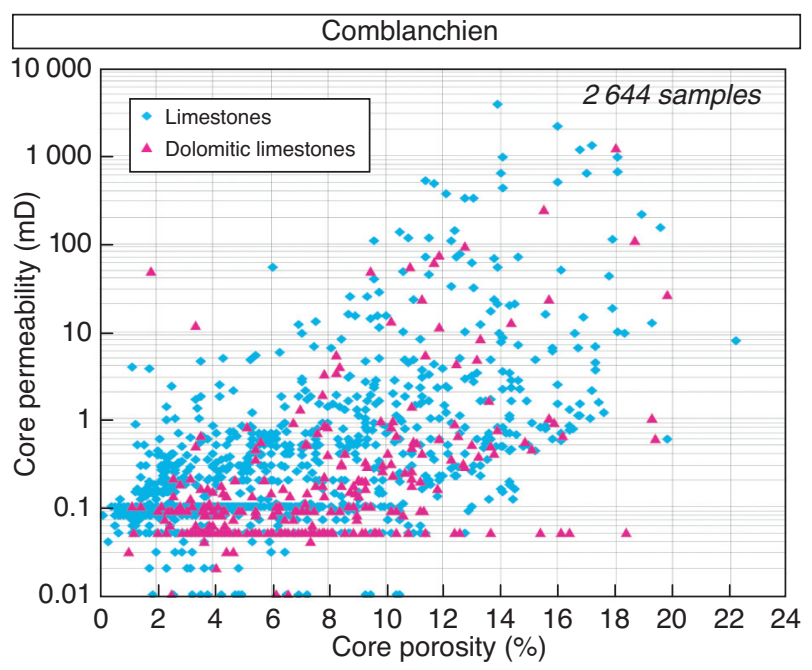

Figure 25

Comblanchien: petrophysical properties of dolomitic and non dolomitic limestones. 


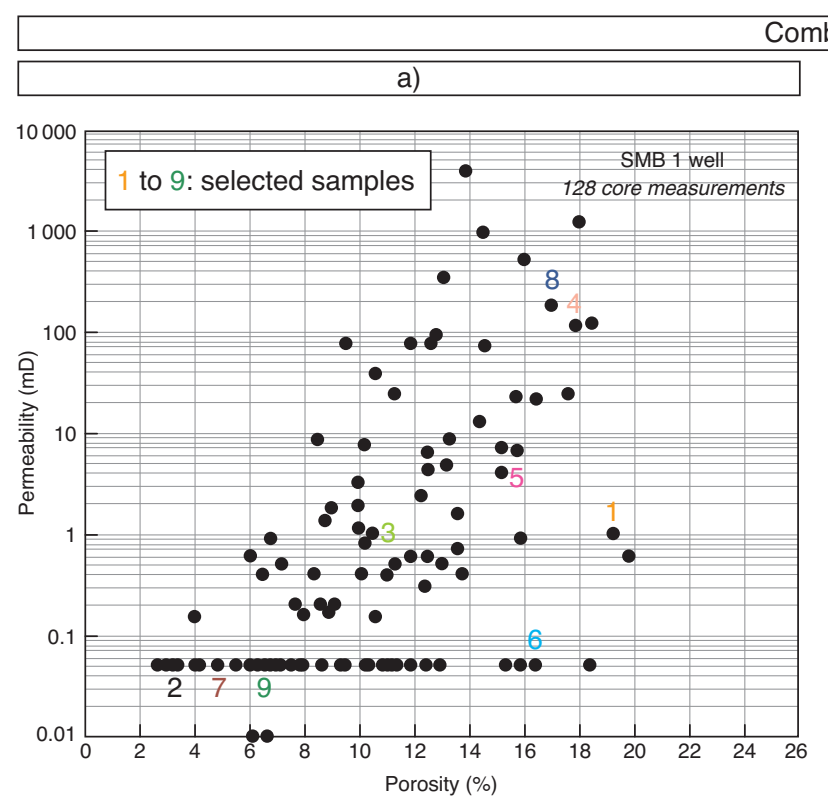

Figure 26

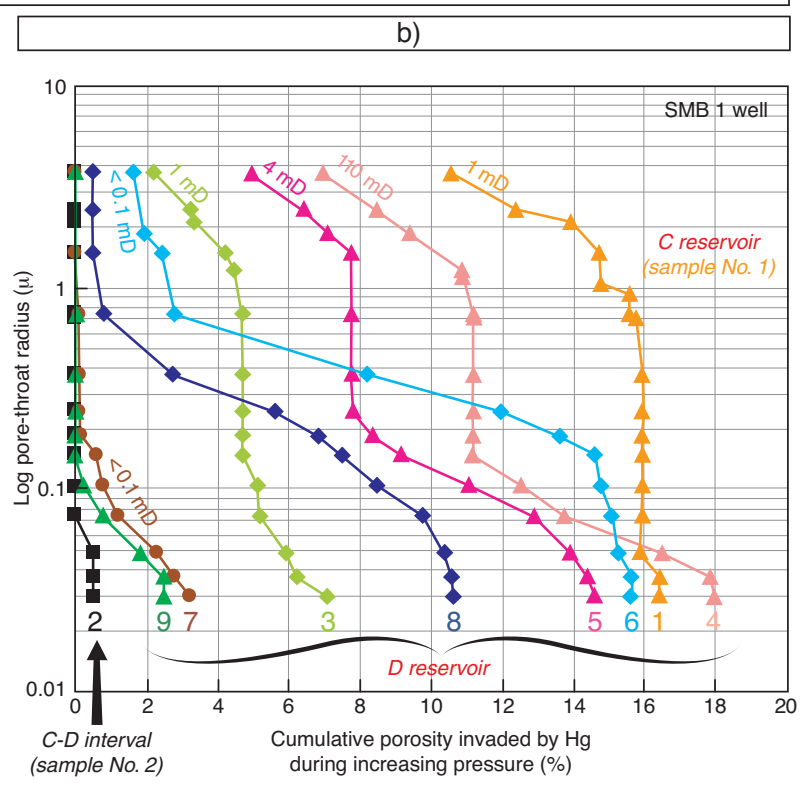

Comblanchien (SMB 1 well): selection of nine measured samples a) used for plotting the pore-throat radius and the porosity b).

- for the FDB 1 well already chosen for the description of the other formations (cuttings - ELAN porosity comparison, Fig. 30), the Dalle Nacrée computed porosity is systematically lower (2-3\%) than the porosity measured on the 48 core-plugs. These discrepancies can be attributed to the clay mineralogy chosen as input in the ELAN parameters. Pellenard et al. (2006) described the clay fraction on the cores of the boreholes drilled by ANDRA ${ }^{(3)}$ in the HauteMarne district (at about $125 \mathrm{~km}$ eastward the PICOREF Sector) as a mixing of illite and kaolinite. But the clay fraction chosen for the FDB 1 well computation is montmorillonite as shown above (Fig. 15).

\subsubsection{Porosity - Air Permeability Cross-Plot}

The scatter of points (Fig. 31a) shows that the three rock fabrics of the Dalle Nacrée formation (grainstone, packstone, and mud-dominated fabrics) have different properties (Fig. 31b):

- the grain-dominated fabrics: grainstones and packstones, deposited in the coarse upper part of the Dalle Nacrée sequences, have the best petrophysical properties ( $K$ max: $1000 \mathrm{mD}$ ) distributed along a typical calcarenite law;

- the mud-dominated fabrics: the packstones, the wackestones, and the mudstones, deposited at the lower part of the sequences, have very low permeability values $(<2 \mathrm{mD})$. The wackestones and packstones porosity is higher (max: $16 \%$ ) than the mudstones one (max: $8 \%$ ), the porositypermeability law is quite different of the calcarenitic material (grainstone-packstone);

(3) ANDRA: Agence Nationale pour la gestion des Déchets Radioactifs.
- the microfissured and microstylolitized limestones (all textures) are characterized by a low porosity $(<10 \%)$ and an high permeability (max: $200 \mathrm{mD}$ ).

\subsubsection{Porosity and Pore-Throat Radius (Mercury Injection Tests on the SMB 1 Reference Well)}

Nine samples were selected among the 40 available ones (Fig. 32a) from the different hydraulic units of the Dalle Nacrée: A-B inter-reservoir, B reservoir, and B-C inter-reservoir (see SMB 1 well layering Fig. 13). The nine curves of porosity versus pore-throat radius show that (Fig. 32b):

- the mud-dominated limestones of the two inter-reservoir intervals: A-B (samples No. 1, 2,3) and C-D (sample No. 9), present poor petrophysical properties (porosity: 4-9\%, permeability: $0.3-4 \mathrm{mD}$ ), and contain only reduced pore space with micro-connections;

- the granular limestones from the B reservoir (samples No. 4 to 8 ) contain both a micro- and a macro-connected porosity. The pore-throat radii are very small $(<0.1$ micrometer $)$, and the permeability values range from 18 to $76 \mathrm{mD}$ resulting from the importance of macroporosity.

We find again the two populations described above for the porosity-permeability plots.

\subsubsection{Flow Tests Results}

The flow rate measured in the Dalle Nacrée formation (98 available values) ranges from 0.01 to $8 \mathrm{~m}^{3} / \mathrm{h}$, but higher flow rates (14 to $19 \mathrm{~m}^{3} / \mathrm{h}$ ) were measured in two wells, respectively Gisy-les-Nobles 3 and SMB 1. 


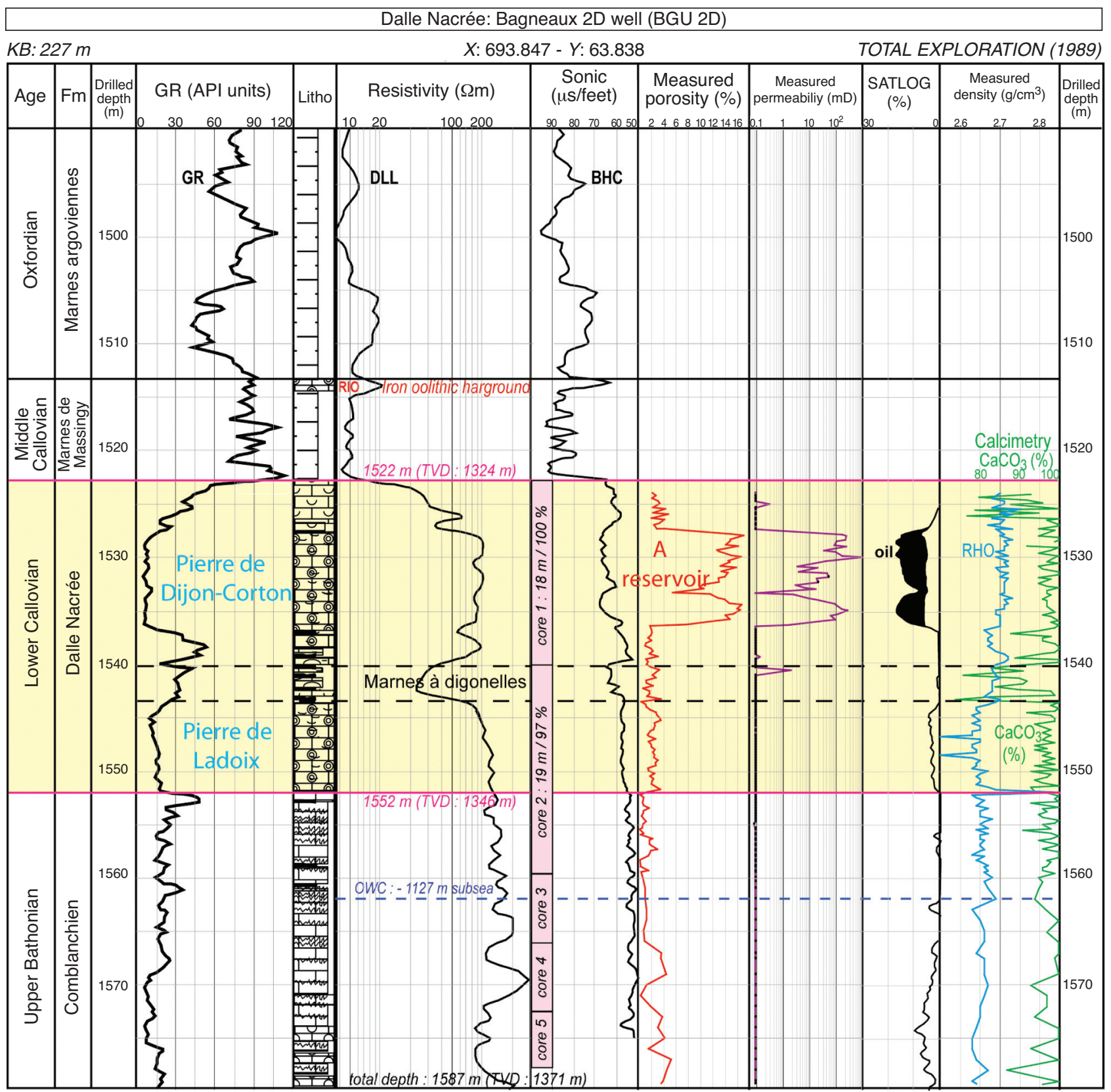

Figure 27

Dalle Nacrée limestones: Bagneaux 2D well chart (BGU 2D). Note the presence of oil-bearing reservoir A layer and the stacking of the two systems.

Contrary to the Oolithe Blanche, testing was performed in front of cored interval allowing test evaluation. A lot of tests are oil producing or diphasic that hinders the extrapolation to water-bearing formations (diagenesis, wettability).

\subsubsection{In Summary}

It is interesting to see that the same depositional texture of the Oolithe Blanche and the Dalle Nacrée can display distinctive properties due to the different diagenesis.
At the same scale, in the Comblanchien, the best reservoir properties are different from the Dalle Nacrée and mainly related to microfissuration and/or stylolithisation. But the sample scale does not always reflect the reservoir scale, and the good reservoir intervals in the Comblanchien are probably related to few grainy macroporous levels (Fig. 24a). It is clear in the depth plot of the SMB 1 reference well (Fig. 13) where the porosity of the Comblanchien D reservoir 


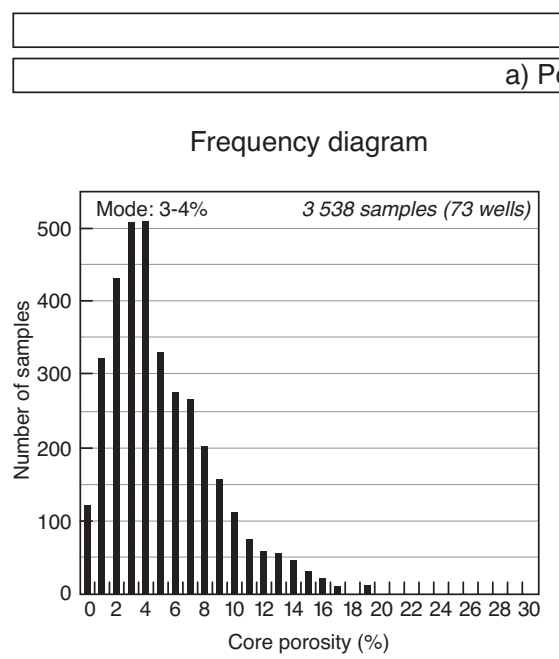

\section{Dalle Nacrée}

a) Porosity

Frequency cumulative curve
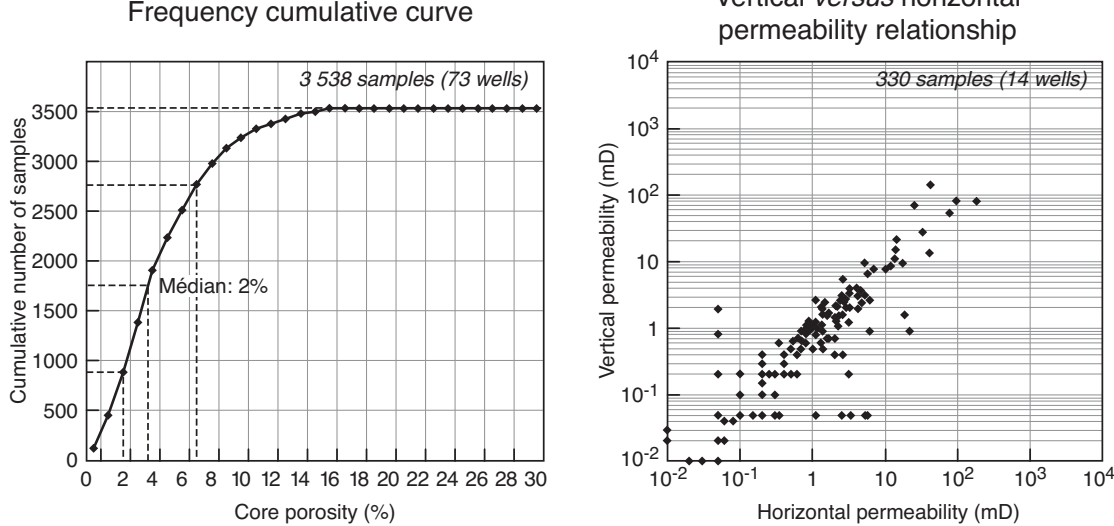

Figure 28

Dalle Nacrée: porosity a) and permeability b) core measurements.

is similar to the porosity of the Dalle Nacrée A and B reservoirs. If the $\mathrm{D}$ reservoir was related to microfissuration and/or stylolitisation, then the porosity would be much lower for similar permeabilities.

The cumulative cross-plot (Fig. 33) of all the available porosity-permeability data for the three formations of the carbonated Middle Jurassic shows that the most permeable reservoirs are composed by the Dalle Nacrée and the Comblanchien macroporous carbonates, whereas the microporous Oolithe Blanche limestones have very low permeabilities.

Paradoxically, the main pore space volume is distributed in the Oolithe Blanche, but this great volume seems inefficient unusable. That will be the great challenge of understand why the Oolithe Blanche is a powerful aquifer.

\section{DISCUSSION}

A specific feature of Paris Basin is that the most accessible and relatively best known large-scale saline aquifer to be considered for $\mathrm{CO}_{2}$ storage is formed by carbonate sediments. In the eastern and central part of the Paris Basin, Upper Bathonian to Lower Callovian deposits have been extensively explored since 50 years, and locally exploited by oil industry, whereas in several parts of Paris suburbs since 25 years geothermal energy has been extracted from Bathonian carbonate units, part of which represent the continuation of Oolithe Blanche formation westwards (Rojas et al., 1990). In addition, the Dogger carbonates were carefully described in the Meuse/Haute-Marne region, ca. $100 \mathrm{~km}$ east of the PICOREF Sector, because they form the immediate substratum of the Callovo-Oxfordian clay-rich formation chosen to experiment a concept of nuclear waste repository (ANDRA, 2005). In any of these three contexts, the hydraulic properties of the sediments and the connectivity between flow units represent key features. Academic research was therefore constantly promoted to improve interpretations drawn from the material collected by industry. Since Purser's pioneer work and first model of the Dogger carbonate platform (Purser, 1972), several studies benefiting from additional data and new concepts (e.g., sequence stratigraphy) could refine the representation in terms of layers dating, stratigraphic correlation, sediment-type distribution and palaeo-geographic interpretation (Gaumet et al., 1996; Clémence et al., 2005; Caspard et al., 2006). Despite this considerable and long-lasting effort, there is no existing model available today to relate facies (or facies succession) and rock type, and to give some handle for statistically deducing reservoir properties from sediment description. This situation is not peculiar to the carbonate formations of the Paris Basin. The same statement can be made for most - if not all - carbonate series: "Carbonate reservoir evaluation has been a high priority for researchers and oil and gas producers for decades, but the challenges presented by these highly heterogeneous rocks seem to be never-ending. From initial exploration through mature stages of production, geoscientists, petrophysicists and engineers work together to extract as much information as possible from their data to produce maximum reserves from the ground" (Akbar et al., 2000). At least, two causes explain why carbonate sedimentary rocks resist analytical methods that are successful in the context of siliciclastic sedimentary rocks: importance of biological processes and environmental parameters in their edification and deposition, drastic effects of diagenesis on their mineral composition and petrophysical properties. The variability of the carbonates factory during 


\section{KB: $104 \mathrm{~m}$}
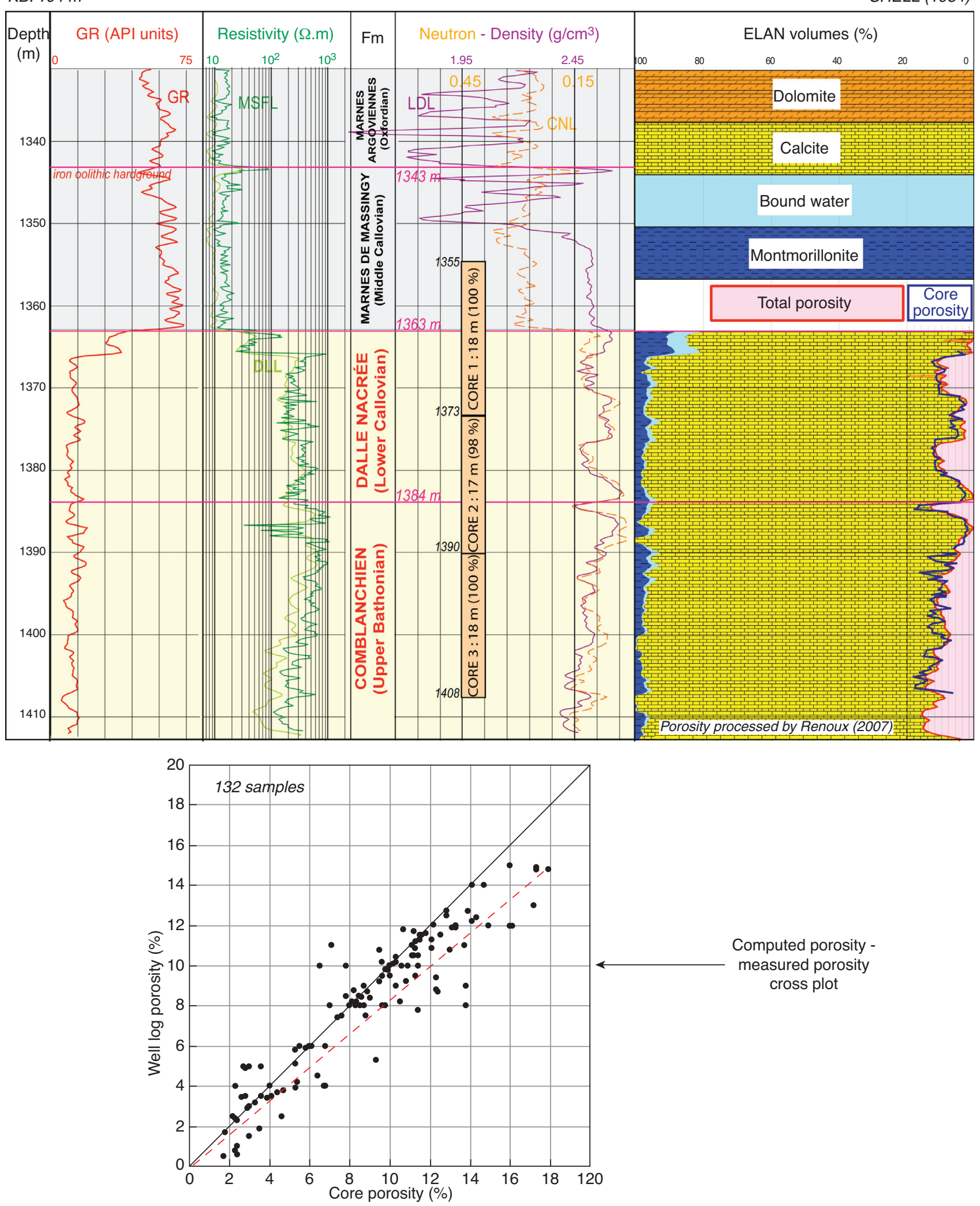

Computed porosity measured porosity cross plot

Figure 29

Comblanchien - Dalle Nacrée: $\log$ /core porosity comparison (SMB 18 well). 
a)

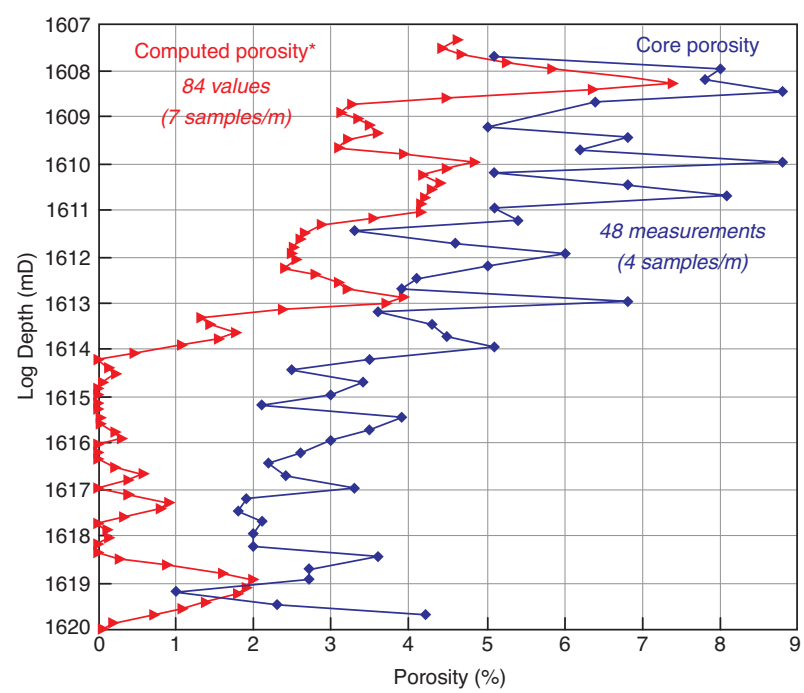

b)

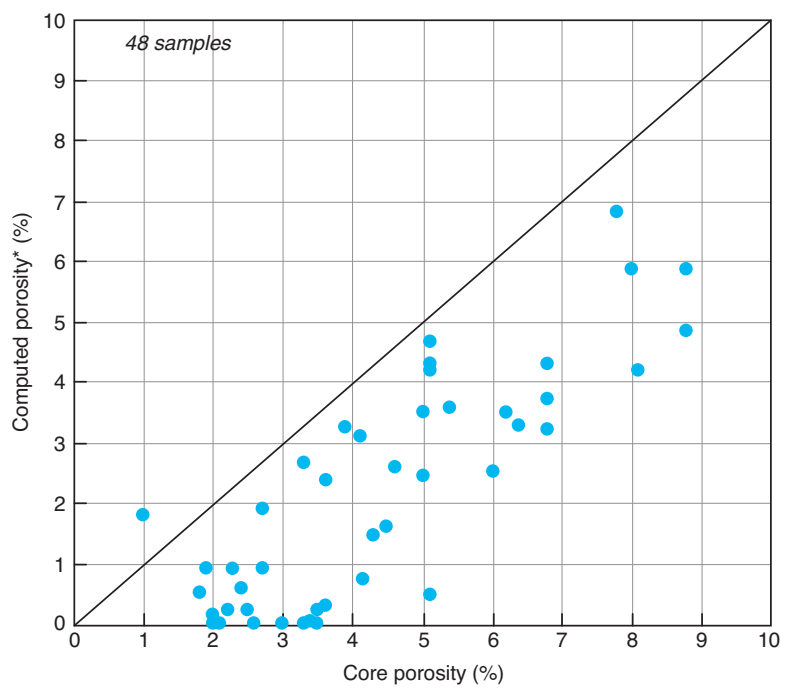

${ }^{*}$ Computed porosity processed by Renoux in 2007 (ELAN software)

Figure 30

Dalle Nacrée. Limestone: log/core porosity comparison (FDB 1 well). a) Depth log, b) cross-plot. See logs Figure 15.

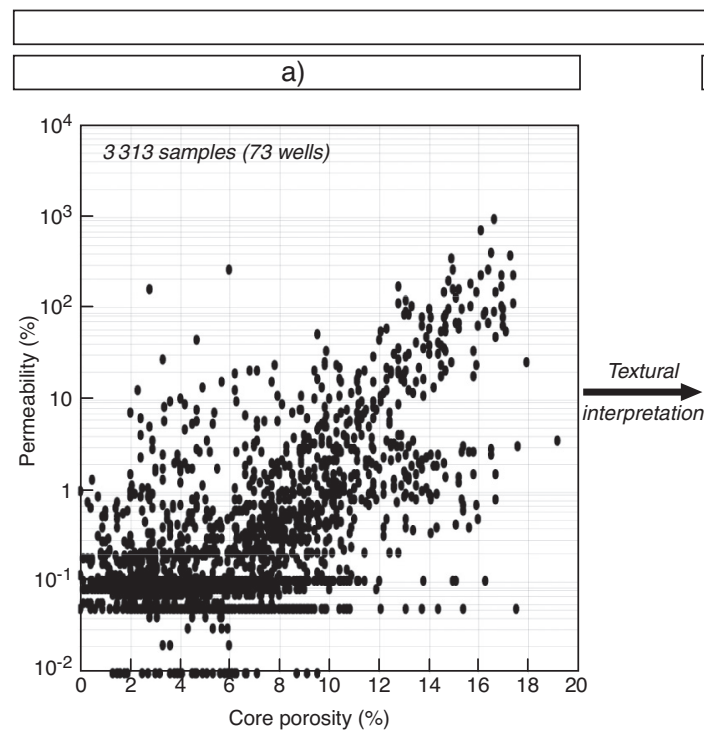

Dalle Nacrée

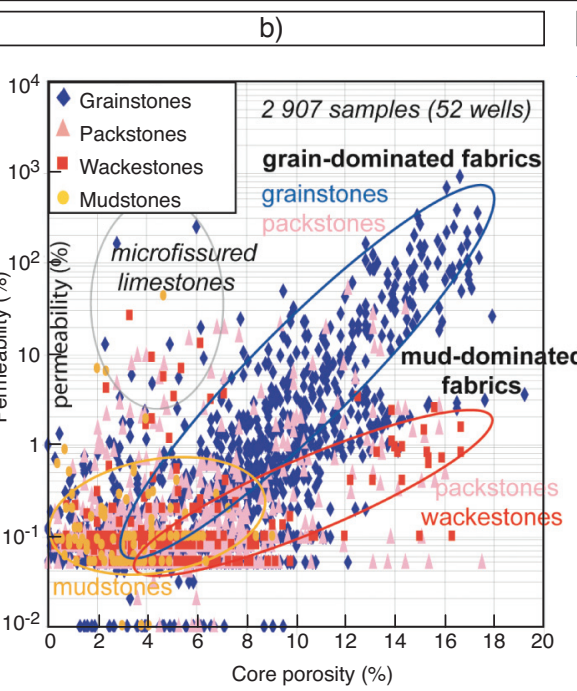

c)

Figure 31

Dalle Nacrée: porosity - air permeability cross-plot a), rock fabric interpretation b), and thin sections c).

geologic times increase this complexity despite constant environmental factors.

What remains - after much research - a puzzling problem for petroleum geology and reservoir engineering is likely to represent a major, possibly insuperable barrier for $\mathrm{CO}_{2}$ storage in aquifer, because in this case:
- reservoir characterisation and modelling is required at a larger scale, up to several tens of $\mathrm{km}$ (instead of few $\mathrm{km}$ most of the time for hydrocarbon fields);

- the available number of wells will be comparatively much lower, and the distance from one well to the other much longer; 


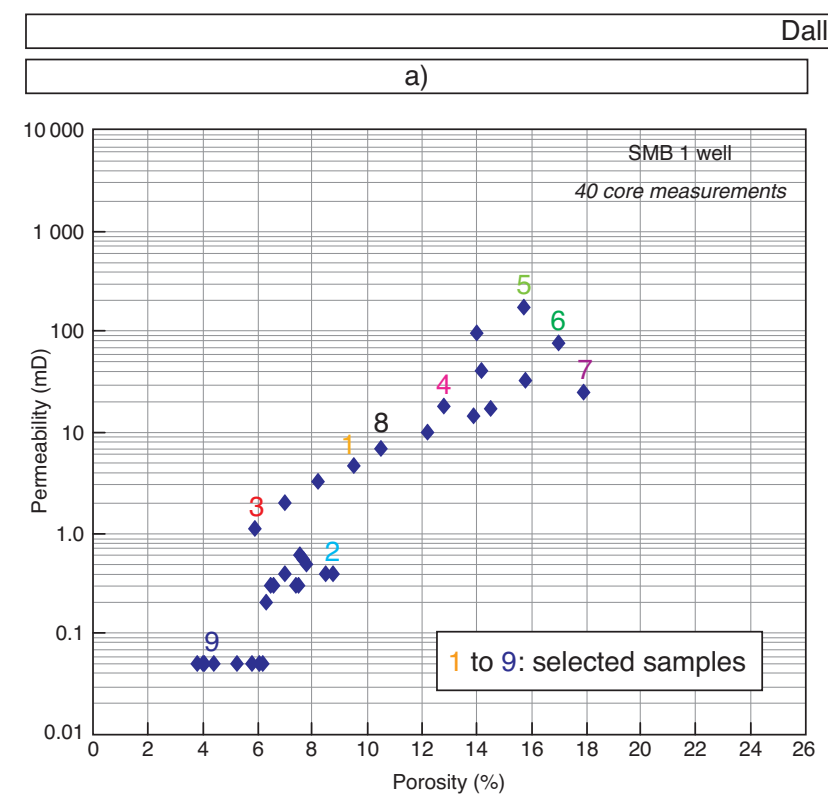

Dalle Nacrée

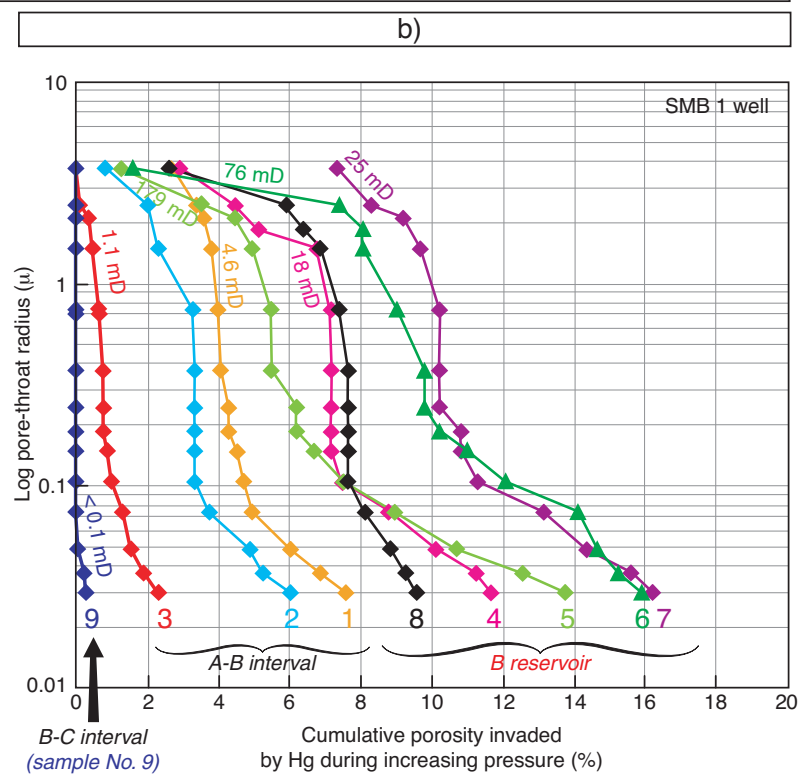

Figure 32

Dalle Nacrée (SMB 1 well): selection of nine measured samples a) used for plotting the pore-throat radius and the porosity b).

- the behaviour of the injected $\mathrm{CO}_{2}$ during a long time for mass balance in a complex architecture could be unpredictable.

Adressing such a challenge calls for renewed techniques and methods in the exploration surveys to be undertaken specifically for $\mathrm{CO}_{2}$ storage in aquifer. More data should be collected from less wells. Intelligent wells, at the cutting edge of drilling and logging technology, become now available in petroleum industry, and should develop in a growing way. Calibrated by special core analysis, they provide more and more detailed data, particularly on pore-space fabric, e.g., Nuclear Magnetic Resonance (NMR) logging tools and comparison with NMR mercury injection measured on core samples). This technical perspective is promising for $\mathrm{CO}_{2}$ storage, nevertheless it has a price, that should be considered for the future economics of $\mathrm{CO}_{2}$ Capture and Storage (CCS) industry. Until such sophisticated material can be used, most of site-characterisation studies in the years to come will have to use conventional - and sometimes old - material accumulated mainly by oil and gas industry. The database of petrophysical properties presented in this article illustrates this situation.

Noteworthy this database comes from activities unrelated to $\mathrm{CO}_{2}$ underground storage facilities. A great part of its failings stems from this origin. Its making is purely opportunist. The cost of creation of data is too expensive to neglect old ones above all relinquished exploration areas.

The main part of the database is made of the following parameters, related to core samples:

- sediment description, i.e., the carbonate depositional fabric (grainstone, wackestone, packstone, mudstone...), with

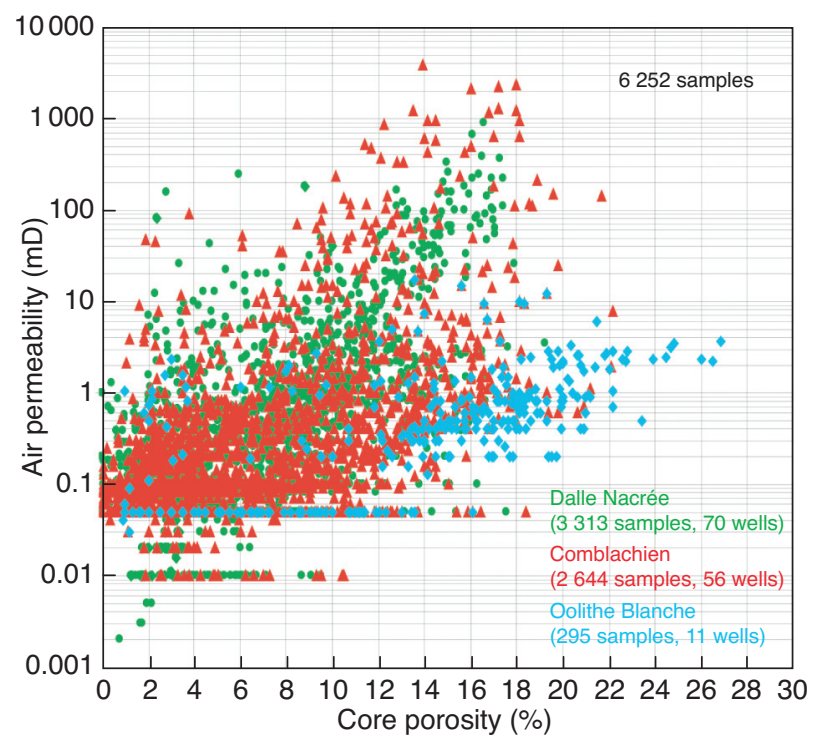

Figure 33

Composite porosity-permeability cross-plot overlying the three carbonated formations of the Middle Jurassic carbonates in the PICOREF Sector.

few additional information on the content (e.g., oolithic, bioclastic...), the degree of cementation, and the probable palaeo-environment (e.g., tide-dominated, inner shelf...);

- measured values of porosity $(\Phi)$ and permeability $(K)$.

Comparing depositional fabric and $\Phi-K$ values was generally deceiving. The attribution of fabric is useful, however, when 
many data are available in a large spectrum of values, because it creates sub-sets of samples easier to interpret (Fig. 24). Grainstone is originally a far better reservoir facies than wackestone, packstone or mudstone, but compaction, diagenesis and other post-depositional effects obliterated most of the original features. Cementation, stylolitisation, or micro-fissuration appear much more significant characters than depositional fabric to determine $\Phi-K$ trends. None of the grainstone carbonates preserved their primary $\Phi-K$ trend in Oolithe Blanche formation (Fig. 16b), and only few of them in Comblanchien formation (Fig. 24a: "intergranular connected porosity"). In Dalle Nacrée formation, the preservation is much better (Fig. 31b). In the latter case, oil saturation and the overall isolated, non-connected character of the reservoir units could contribute to the absence of cementation. Preserved grainstone facies can reach locally very fair "matrix type" reservoir properties $(\Phi 15 \%, K$ hundreds of $\mathrm{mD})$. Conversely, wackestone, packstone and mudstone have initially poor reservoir properties, but due to stylolitisation or micro-fissuration, they can gain much better permeability value (Fig. 24b-d). However, this permeability improvement is achieved without any effect on porosity, and the best resulting values $(\Phi 10-12 \%, K 100 \mathrm{mD})$ are typically "fracturetype" reservoir properties.

In the central part of the Paris Basin, in Paris suburban areas where geothermal energy is exploited from Bathonian carbonates (notably in the "Ensemble Oolithique" formation, deposited as the Oolithe Blanche formation as an oolithic barrier), a very heterogeneous distribution of permeability $(K)$ has been observed (Rojas et al., 1990). Inside thick carbonate sequences that present overall moderate to poor $K$ values, discrete metre-scale units have been identified with very high $K$ values, up to $21 \mathrm{D}$ ! These layers are too thin to be correlated at the $\mathrm{km}$-scale distance that separates two wells, nevertheless, some type of connectivity does exist (role of fracturation?), able to explain the fair productivity of many geothermal wells since two decades. A major question, not solved for the moment, is to know if such flow units exist in other parts of the Paris Basin, and to understand the origin of high $K$ values. According to the petrographic observations made, it seems that the reservoir properties of these layers were preserved from cementation. However, the diagenetic history is complex, with several cycles of cementation/redissolution, so it is possible that an episode of re-dissolution played a role. Another problem is systematic deterioration of the reservoir properties towards the outcrops, where the bored water wells in the Bathonian are frequently unproductive. We do not know exactly the limits of this effect.

The database includes also some data on the pore-type distribution, acquired with mercury injection tests. Micropores and associated pore throats (lower than $1 \mu \mathrm{m}$ ) are commonly related to intraparticle porosity. Large pores and pore throats are commonly related to intergranular to moldic porosity; they hold and transmit fluids whereas micropores may hold irreducible water saturation. Only the macro-connected porosity takes a significant part to the permeability which is a function of pore-size distribution (Lucia, 1983, 1995, 1999). Micro-porosity is the only part of porosity left in the sediment by cementation. This is the case of Oolithe Blanche formation in general. Intense diagenetic cementation reduced the pore-throat size of connections between macro-pores, but not the macro-porosity itself. In contrast, some new, large connections were created by stylolitisation or micro-fissuration, probably in particular directions. This is the case in some wackestone, packstone or mudstone facies of the Comblanchien formation (Fig. 24) or Dalle Nacrée formation (Fig. 31). Strongly dolomitized layers, observed in the Comblanchien formation either at Saint-Martin-de-Bossenay oilfield, or at Plombières-lès-Dijon outcrops (in Burgundy), result from another diagenetic effect. They should be considered of local value, maybe linked to specific structural position (proximity of a fault?), because more diffuse dolomitization is widespread and does not induce any significant shift in the $\Phi-K$ values. In the perspective of future exploration involving new wildcats any logging tool able to investigate the structure of porosity should be particularly promoted. We think here, particularly, to NMR logging tools (e.g., Akbar et al., 2000).

Finally, the database presented here contains few results of porosity $(\Phi)$ appraisal obtained through "quick-screening" techniques, particularly useful at a given step of exploration:

- ELAN calculations from conventional sets of $\operatorname{logs}$ (Fig. 15, 29);

- measurements from cuttings (Lenormand, 2008).

This is due to the fact that most of the French wildcats logs are not yet digitized and that remaining cuttings from wells are protected as proof material. These two products (logs and cuttings) are the more common in well data, so they have the great quality of ubiquity, but they are either on basic type or unexploited by new devices.

Comparison has been possible between the two estimations, and with $\Phi$ values from core samples, unfortunately on too limited case studies. In Oolithe Blanche and Comblanchien formations at Fontenay-de-Bossery 1 well a large discrepancy was observed between screening methods (Fig. 19). The ELAN $\Phi$ profile is far below the cuttings one. In Comblanchien and Dalle Nacrée formations at Saint-Martinde-Bossenay 18 well (Fig. 29), or in Dalle Nacrée formation at Fontenay-de-Bossery 1 well (Fig. 30), the ELAN $\Phi$ profile is relatively close to core-sample $\Phi$ profile. In both case the values of core-sample $\Phi$ are 1 to $3 \%$ higher than the values computed through the ELAN software and methodology. Such comparisons between results from different tools, and calibration of screening techniques, or inter-calibration between methods, are extremely important issues for the future efficiency of exploration surveys applied to $\mathrm{CO}_{2}$ storage in aquifers. Here they are only drafted. If measurements on core samples are considered as the more realistic values, 
then log-derived values (ELAN) with the adopted assumptions (in particular clay fraction made of smectite) appear as an under-estimation, whereas cuttings-derived values appear as a slight over-estimation.

The present paper, and the synthesis paper on PICOREF (Brosse et al., this issue), also illustrate the interest of outcropping equivalents to study many features of the geologic layers investigated: sedimentary facies, sequence stratigraphy (Gaumet et al., 1996; Gaumet, 1997), diagenesis (Clemence et al., 2005; Caspard et al., 2006), fracturation. In that respect, the Dogger aquifers of the Paris Basin can be particularly well documented, in a very economic way, by observations made on the vivid cutting edges of many quarries in Burgundy.

\section{CONCLUSION}

The important well database (about seven thousands petrophysical data) gathered for the PICOREF Project on the three Middle Jurassic carbonate units: Oolithe Blanche, Comblanchien, and Dalle Nacrée of the south eastern part of the Paris Basin allows to improve the characterization, at the sample scale, of these saline aquifers considered as potential reservoirs for hosting geological storage of $\mathrm{CO}_{2}$ :

- the best matrix permeabilities are measured on the macroporous non cemented granular carbonates from the Comblanchien and the Dalle Nacrée formations;

- the best matrix porosities are measured on the oolithic limestones from the Oolithe Blanche, but these microporous limestones have bad matrix permeabilities $(<5 \mathrm{mD})$. With large exchange/specific surfaces, the microporosity is sensitive to aggressive fluids and dissolution than macroporosity;

- more comparison examples between data sets of various types (cores, logs, cuttings, tests) which are locally disconnected. Over representation of oil-bearing levels.

The higher permeability values are due to microfissuration and stylolithization. Both microfissures and stylolithes can be "closed"/sutured under reservoir pressure conditions, but be open during permeability tests if they are not performed under confining pressure. At the well scale, the most important fluid flows were produced by the Dalle Nacrée (maximum: $19 \mathrm{~m}^{3} / \mathrm{h}$ ). The Comblanchien and the Oolithe Blanche gave lower fluid flows (respectively 3.8 and $1 \mathrm{~m}^{3} / \mathrm{h}$ maximum).

To have a best knowledge of the aquifers, it would be a crucial point to acquire:

- new petrophysical data, particularly on the Oolithe Blanche limestones;

- petrographic and diagenetic data (thin sections) for a good characterization of the small scale heterogeneities;

- the interpretation of the well testing to know the permeability value at the well scale.

\section{ACKNOWLEDGMENTS}

We gratefully acknowledge Benoît Vincent and Bernard Zinsner for their constructive comments.

We also want to thank Patrick Renoux, Roland Lenormand and Jean-Marc Lombard for providing us their results, respectively:

- the Computed Porosity Interpretation for the FDB 1 and SMB 18 wells;

- the drill cuttings porosity measurements for the FDB 1 well;

- the pore-throat size distribution plots from mercury capillary tests on several Oolithe Blanche samples from quarries in Bourgogne.

\section{REFERENCES}

Akbar M., Vissapragada B., Alghamdi A.H., Allen D., Herron M., Carnegie A., Dutta D., Olesen J.R., Chourasiya R.D., Logan D., Stief D., Netherwood R., Russel S.D., Saxena K. (2000) A snapshot of carbonate reservoir evaluation, Oilfield Review, Winter 2000/2001, pp. 20-41.

ANDRA (2005) Référentiel du site de Meuse/Haute-Marne. Tome 1: le site de Meuse/Haute-Marne : étude géologique et état actuel, in Dossier Argile, 2005.

Badinier G. (2007) Caractérisation sédimentologique et pétrophysique de la formation aquifère de l'Oolithe Blanche de SaintMartin-de-Bossenay à partir des analogues de terrain de Bourgogne, Projet PICOREF, Rapport GDF, Réf. DEP.DGS.SPG.CRI.2007.

Brosse E., Badinier G., Blanchard F., Caspard E., Collin P.Y., Delmas J., Dezayes C., Dreux R., Dufournet A., Durst P., Fillacier S., Garcia D., Grataloup S., Hanot F., Hasanov V., Houel P., Kervévan C., Lansiart M., Lescanne M., Menjoz A., Monnet M., Mougin P., Nedellec B., Poutrel A., Rachez X., Renoux P., Rigollet C., Ruffier-Meray V., Saysset S., Thinon I., Thoraval A., Vidal-Gilbert S. (2009) Selection and characterization of geological sites able to host a pilot-scale $\mathrm{CO}_{2}$ storage in the Paris Basin (GéoCarbone-PICOREF), Oil Gas Sci. Technol. - Rev. IFP, this issue.

Carpentier C., Lathuilière B., Ferry S., Sausse J. (2007) Sequence stratigraphy and tectonosedimentary history of the Upper Jurassic of the Eastern Paris Basin (Lower and Middle Oxfordian, Northeastern France), Sediment. Geol. 197, 235-266.

Caspard E., Clémence M.E., Collin P.Y. (2006) Étude sédimentologique et diagénétique dans le Dogger du bassin de Paris. Le champ de St-Martin-de-Bossenay et la carrière de Plombières-lèsDijon, Projet PICOREF - Volet 1, Rapport Université Pierre et Marie Curie.

Clémence M.E., Collin P.Y., Rigollet C. (2005) Étude sédimentologique de la plateforme carbonatée pariso-bourguignonne, Rapport GDF.

Collin P.Y., Courville P., Loreau J.P., Marchand D., Thierry J. (1999) Séries condensées et indice de préservation d'unité biostratigraphique : exemple de l'ennoiement de la plate-forme nord-bourguignonne (France) au Callovo-Oxfordien, C.R. Acad. Sci. II A 328, 105-111.

Collin P.Y., Loreau J.P., Courville P. (2005) Depositionnal environments and iron ooïd formation in condensed sections (CallovianOxfordian, south-eastern Paris Basin, France), Sedimentology 52, 969-985.

Delmas J., Houel P., Vially R. (2002) Paris Basin - Petroleum potential, Rapport IFP n 59994. 
Delmas J. (2006) Étude pétrophysique des aquifères du Dogger carbonaté dans le Secteur d'étude de PICOREF. Logs pétrophysiques : mesures sur carottes, Projet PICOREF, Volet 3, Rapport IFP n ${ }^{\circ} 59465$.

Delmas J. (2007) Étude pétrophysique des aquifères du Dogger carbonaté dans le Secteur d'étude de PICOREF. Relation entre la porosité et la perméabilité mesurées sur carottes, Projet PICOREF, Volet 3, Rapport IFP n ${ }^{\circ} 59791$.

Delmas J. (2008) Interprétation géologique des résultats des porosimétries mercure sur le Dogger carbonaté du puits SaintMartin-de-Bossenay 1 (SMB 1), Bassin de Paris, Projet PICOREF, Volet 2, Rapport IFP n ${ }^{\circ} 60472$.

Dromart G., Allemand P., Garcia J.P., Robin C. (1996) Variation cyclique de la production carbonatée au Jurassique le long d'un transect Bourgogne - Ardèche, Est-France, B. Soc. Géol. Fr. 167, 3, 423-433.

Granier B. (1995) A sedimentological model of the Callovian oolithe reservoir of the Villeperdue oil field, Paris Basin (France), Petrol. Geosci. 1, 145-150.

Floquet M., Laurin B., Laville P., Marchand D., Menot J.C., Pascal A., Thierry J. (1989) Les systèmes sédimentaires bourguignons d'âge Bathonien terminal - Callovien, Bull. Centres Rech. Explor.Prod. Elf-Aquitaine 13, 1, 133-165.

Garcia J.P., Laurin B., Sambet G. (1996) Les associations des brachiopodes du Jurassique moyen du Bassin de Paris : une échelle biochronologique ponctuée de niveaux repères pour la contrainte des corrélations séquentielles à haute résolution, B. Soc. Géol. Fr. 167, 3, 435-451.

Gaumet F., Garcia J.P., Dromart G., Sambet G. (1996) Contrôle stratigraphique des faciès, géométries et profils de dépôt de la plateforme carbonatée bourguignonne au Bathonien-Callovien, B. Soc. Géol.Fr. 167, 3, 409-421.

Gaumet F. (1997) Fondements géologiques pour la modélisation stratigraphique des systèmes carbonatés. Le Jurassique moyen de l'Angleterre à la Méditerranée, Thèse, Université C. Bernard Lyon I.

Guillocheau F. et al. (2000) Meso-cenozoïc geodynamic evolution of the Paris Basin: 3D stratigraphic constraints, Geodyn. Acta 13, 189-246.

Houel P. (2008) Description géologique et hydraulique préparatoire à l'interprétation de la zone PICOREF (SE du bassin de Paris), Projet PICOREF, Rapport IFP n ${ }^{\circ} 60269$.

Javaux C. (1992) La plateforme parisienne et bourguignonne au Bathonien terminal et au Callovien, Mém. Géol. Univ. Dijon, 16, 342 p., 177 figures.

Lenormand R., Fonta O. (2007) Advances in measuring porosity and permeability from drill cuttings, SPE/EAGE Reservoir Characterization and Simulation Conference, Abu-Dhabi, U.A.E, 28-31 October 2007, SPE 111286.
Lucia F.J. (1983) Petrophysical parameters estimated from visual description of carbonate rocks : a field classification of carbonate pore space, J. Petrol. Technol. March, 626-637.

Lucia F.J. (1995) Rock-fabric/petrophysical classification of carbonate pore space for reservoir characterization, AAPG Bull. 79, $1275-1300$

Lucia F.J. (1999) Carbonate reservoir characterization, SpringerVerlag, ISBN 3-540-63782-6, 226 p.

Marrast J. (1959) Rapport de fin de carottage continu de SaintMartin-de-Bossenay 1 (1376-1787 m), Rapport IFP n 3342.

Marrast J. (1960) Étude de la morphologie des pores de 100 échantillons provenant du sondage de SMB 1 (COPESEP), Rapport IFP $\mathrm{n}^{\circ} 5083$.

Pellenard P., Deconinck J.F. (2006) Mineralogical variability of Callovo-Oxfordian clays from the Paris and the Subalpine basin, C.R. Geoscience 338, 854-866.

Pittman E. (1971) Microporosity in carbonate rocks, AAPG Bull.55, 10, 1873-1881, 9 figures.

Purcell W.R. (1949) Capillary pressures: their measurement using mercury and the calculation of permeability therefore, Trans. AIME 186, 39-48.

Purser B.H. (1967) Le Comblanchien : interprétation de son milieu de sédimentation, Extrait de la Revue de l'Institut Français du Pétrole et Annales des combustibles liquides XXII, 4, 591-594.

Purser B.H., Loreau J.P. (1972) Structures sédimentaires et diagénétiques précoces dans les calcaires bathoniens de la Bourgogne, Bull. BRGM, II, IV , 2, 19-47.

Purser B.H. (1975) Sédimentation et diagenèse précoce des séries carbonatées du Jurassique moyen de Bourgogne, Thèse État Sci., Univ. Paris-Sud Orsay, 384 p.

Purser B.H. (1989) Plate-formes carbonatées : exemple du Jurassique moyen du Bassin de Paris, Dynamique et méthodes d'étude des bassins sédimentaires, Association des sédimentologistes français, Ed. Technip, Chap. 9, pp. 145-163.

Rafavich F., Kendall C., Todd T. (1984) The relationship between acoustic properties and the petrographic character of carbonate rocks, Geophysics 49, 1622-1636.

Renoux P. (2008) Aquifers: wireline log study Limoreau 101 well, Project ANR-CO ${ }_{2}$, Oil Gas Sci. Technol. - Rev. IFP, this issue.

Rojas J., Giot D., Le Nindre Y.M., Criaud A., Fouillac C., Brach M., Menjoz A., Martin J.C., Lambert M. avec la collaboration de Chiles P.P., Fouillac A.M., Pauwels H. (1990) Caractérisation et modélisation du réservoir géothermique du Dogger du bassin parisien, France, Document du BRGM n ${ }^{\circ} 184$.

Zinsner B., Pellerin F.M. (2007) A geoscientist guide to petrophysics, IFP Publications, Ed. Technip.

Final manuscript received in December 2009 Published online in May 2010 or distributed for profit or commercial advantage and that copies bear this notice and the full citation on the first page. Copyrights for components of this work owned by others than IFP must be honored. Abstracting with credit is permitted. To copy otherwise, to republish, to post on servers, or to redistribute to lists, requires prior specific permission and/or a fee: Request permission from Documentation, Institut français du pétrole, fax. +33147527078 , or revueogst@ifp.fr. 